\title{
Bacteriophages and their derivatives for the treatment and control of food-producing animal infections
}

\author{
Carla Carvalho ${ }^{a, b} \mathbb{D}$, Ana Rita Costa ${ }^{a}$, Filipe Silva ${ }^{c}$ and Ana Oliveira ${ }^{a}$

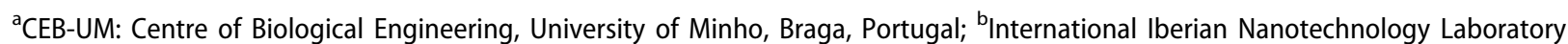 \\ (INL), Braga, Portugal; 'CECAV-UTAD, Animal and Veterinary Research Centre, University of Trás-os-Montes e Alto Douro, Vila Real, \\ Portugal
}

\begin{abstract}
Nowadays, the world is facing an increasing emergence of antibiotic resistant bacteria. Simultaneously, the banning of some existing antibiotics and the lack of development of new antimicrobials have created an urgent need to find new alternatives against animal infections. Bacteriophages (phages) are naturally occurring predators of bacteria, ubiquitous in the environment, with high host specificity and harmless to animals. For these reasons, phages and their derivatives are being considered valuable antimicrobial alternatives and an opportunity to reduce the current use of antibiotics in agri-food production, increasing animal productivity and providing environmental protection. Furthermore, the possibility of combining phage genetic material with foreign genes encoding peptides of interest has enabled their use as vaccine delivery tools. In this case, besides bacterial infections, they might be used to prevent viral infections. This review explores current data regarding advances on the use of phages and phage-encoded proteins, such as endolysins, exolysins and depolymerases, either for therapeutic or prophylactic applications, in animal husbandry. The use of recombinant phage-derived particles or genetically modified phages, including phage vaccines, will also be reviewed.
\end{abstract}

\section{ARTICLE HISTORY}

Received 12 April 2016

Revised 6 December 2016

Accepted 8 December 2016

Published online 4 January

2017

\section{KEYWORDS}

Food-producing animals; antimicrobials; phages;

lysins; vaccines

\section{Introduction}

Livestock production frequently involves raising animals in confined conditions, promoting the easy and fast spread of infectious diseases. To prevent and treat these diseases, antibiotics have been a common practice for decades. Indeed, more than one hundred different antimicrobials have been used in food-producing animals (Hao et al., 2014). In addition to their therapeutic use, some antibiotics modulate the digestive flora and immune system and thus have been used as growth promoters to increase animal growth and feed conversion rates. However, this has been leading to antibiotic overuse, threatening their efficacy due to the emergence and spread of antibiotic resistant bacteria (Page \& Gautier, 2012), and causing a negative environmental impact. Currently, the amount of antibiotics used in livestock is by far the largest portion of all antibiotics used worldwide, exceeding those used in human medicine (Mellon et al., 2001), mostly from the same class in both medical fields (Phillips et al., 2004). In 2010, approximately 63,151 tons of antimicrobials were used in livestock worldwide. By 2030, this consumption is expected to increase by $67 \%$ (Hollis \& Ahmed, 2013, Van Boeckel et al., 2015). Most of these antibiotics are used for nontherapeutic purposes, as growth promotion and disease prevention (Mellon et al., 2001). Tetracyclines are the most commonly used veterinary antibiotics followed by sulfonamides and macrolides (Kim et al., 2011).

Overall, the continuing increase and emergence of antimicrobial resistance of bacteria, the lack of novel and effective alternative drugs and the banning of antimicrobials as growth promoters in some countries emphasize the urgent need to develop and implement alternative antimicrobials in Veterinary Medicine (Aarestrup et al., 1998).

Bacteriophage and their derivatives are being considered valuable alternative antimicrobial solutions. Bacteriophages (phages) are viruses that specifically infect bacteria, being harmless to humans, animals and plants. Their initial discovery in 1917 by d'Herelle led to promising studies regarding their antimicrobial efficiency, but they were stalled in the United States and Western Europe by the development of antibiotics. Nevertheless, research on phages and their medical applications continued particularly in the former Soviet Union and Eastern Europe (Sulakvelidze et al., 2001). 
More recently, with the emergence of multiple antibiotic-resistant bacteria, the interest in phage therapy was renewed (Goodridge \& Bisha, 2011, O'Flaherty et al., 2009). Besides using the whole phage particle, it is also possible to use their heterologous expressed proteins with antimicrobial interest (as lysins and depolymerases) (Oliveira et al., 2013; Schmelcher et al., 2012a; Young, 2013, 2014). Furthermore, the possibility of using simple methodologies for the genetic modification of phage genomes offers several opportunities to improve their antimicrobial and safety properties, as well as for their prophylactic use as efficient antigen delivery vehicles (phage vaccines) against viruses.

The phage-based solutions applied to animals or animal models described herein aim to highlight the existence of safe and efficient tools to treat and control infections that cause diseases in food-producing animals. These may decrease the need for antibiotics without impairing productivity, while simultaneously offering environmental protection, by reducing the use of agro-chemicals.

\section{The main agents affecting food-producing animals}

There are hundreds of bacteria and viruses causing diseases in food-producing animals, affecting one or more animal species, with the most relevant presented in Table 1.

Bacteria cause a diversity of diseases that vary with the animal species, the agent gateway, the immune response of the animal and the farm sanitation. Likewise, viruses infect specific animals and have outcomes that range from no symptoms to mild and lifethreatening diseases. These infectious diseases adversely affect the profitability of farms, either by animal death, fertility decrease and reduction of animalderived products such as milk, eggs or wool, or by causing low food conversion rates resulting in an increase of food input for the same economic output (Lamy et al., 2012). Furthermore, bacterial and viral diseases in animals have potentially serious impacts on human health. In fact, more than $70 \%$ of all emerging human pathogens over the last years have been derived from pathogens originated from animals or products of animal origin (zoonotic) (Jones et al., 2008; Woolhouse et al., 2005). The World Health Organization (WHO, 2015) has estimated that globally 2.2 million people die each year from foodborne and waterborne diarrhoeal diseases alone.

Approximately, 80 types of bacteria cause disease in poultry industry, such as salmonellosis, pasteurellosis,
Table 1. Bacterial genera and virus families that cause disease in food-producing animals (Bradley et al., 2015; FAO, 2015; Merck, 2015; Persson \& Bojesen 2015; VetBac, 2015).

\begin{tabular}{|c|c|c|c|c|}
\hline & Cattle & Poultry & Pigs & $\begin{array}{c}\text { Small } \\
\text { ruminants }\end{array}$ \\
\hline \multicolumn{5}{|l|}{ Bacterial genera } \\
\hline \multicolumn{5}{|l|}{ Actinobacillus } \\
\hline \multicolumn{5}{|l|}{ Actinomyces } \\
\hline \multicolumn{5}{|l|}{ Anaplasma } \\
\hline \multicolumn{5}{|l|}{ Avibacterium } \\
\hline \multicolumn{5}{|l|}{ Bacillus } \\
\hline \multicolumn{5}{|l|}{ Bibersteinia } \\
\hline \multicolumn{5}{|l|}{ Bordetella } \\
\hline Borrelia & & & & \\
\hline Brachyspira & & & & \\
\hline Brucella & & & & \\
\hline Campylobacter & & & & \\
\hline Chlamydia & & & & \\
\hline Chlamydophila & & & & \\
\hline Clostridium & & & & \\
\hline Corynebacterium & & & & \\
\hline Coxiella & & & & \\
\hline Dermatophilus & & & & \\
\hline Dichelobacter & & & & \\
\hline Ehrlichia & & & & \\
\hline Enterococcus & & & & \\
\hline Erysipelothrix & & & & \\
\hline Escherichia & & & & \\
\hline Francisella & & & & \\
\hline Fusobacterium & & & & \\
\hline Gallibacterium & & & & \\
\hline Haemophilus & & & & \\
\hline Histophilus & & & & \\
\hline Klebsiella & & & & \\
\hline Lawsonia & & & & \\
\hline Leptospira & & & & \\
\hline Listeria & & & & \\
\hline Mannheimia & & & & \\
\hline Moraxella & & & & \\
\hline Mycobacterium & & & & \\
\hline Mycoplasma & & & & \\
\hline Neorickettsia & & & & \\
\hline Nocardia & & & & \\
\hline Pasteurella & & & & \\
\hline Peptoniphilus & & & & \\
\hline Prevotella & & & & \\
\hline Proteus & & & & \\
\hline Pseudomonas & & & & \\
\hline Rhodococcus & & & & \\
\hline Salmonella & & & & \\
\hline Serratia & & & & \\
\hline Staphylococcus & & & & \\
\hline Streptobacillus & & & & \\
\hline Streptococcus & & & & \\
\hline Treponema & & & & \\
\hline Trueperella & & & & \\
\hline Ureaplasma & & & & \\
\hline Yersinia & & & & \\
\hline Virus families & & & & \\
\hline Adenoviridae & & & & \\
\hline Arteriviridae & & & & \\
\hline Asfariviridae & & & & \\
\hline Astroviridae & & & & \\
\hline Birnaviridae & & & & \\
\hline Bornaviridae & & & & \\
\hline Bunyaviridae & & & & \\
\hline Caliciviridae & & & & \\
\hline Circoviridae & & & & \\
\hline Coronaviridae & & & & \\
\hline Flaviviridae & & & & \\
\hline Herpesviridae & & & & \\
\hline Orthomyxoviridae & & & & \\
\hline Papillomaviridae & & & & \\
\hline Paramyxoviridae & & & & \\
\hline Parvoviridae & & & & \\
\hline Picomaviridae & & & & \\
\hline Poxviridae & & & & \\
\hline Reoviridae & & & & \\
\hline Retroviridae & & & & \\
\hline Rhabdoviridae & & & & \\
\hline Togaviridae & & & & \\
\hline
\end{tabular}


tuberculosis, staphylococcosis, streptococcosis, infectious coryza, necrotic enteritis, avian chlamydiosis, colibacillosis and mycoplasmosis (Hao et al., 2014; Lima et al., 2016; Masdooq et al., 2008; Merck, 2015).

In cattle, mastitis (caused e.g. by Staphylococcus spp. or Streptococcus spp.) is an important cause of economic loss due to milk waste, treatment costs and premature culling of animals in severe cases (Heikkilä et al., 2012), while respiratory infections (caused e.g. by Pasteurella spp., Mannheimia spp., Mycoplasma spp. or Pseudomonas spp.) are associated to significant morbidity and mortality (Royster \& Wagner, 2015; Vogel et al., 2001).

In pigs, respiratory diseases are the most important health concern for swine producers nowadays, and are often the result of a combination of primary and opportunistic infectious agents (Brockmeier et al., 2002). Common respiratory diseases where bacteria are responsible for significant economic losses are Mycoplasma pneumonia and pleuropneumonia or Haemophilus parasuis infections. Pasteurella multocida and Bordetella bronchiseptica induce atrophic rhinitis that is also an important predisposing factor for increased respiratory diseases (Brockmeier et al., 2002; Magyar \& Lax, 2002; Merck, 2015; Nedbalcova et al., 2006).

Viruses can also cause several diseases with further complications. In fact, the host's response to the viral infection compromises its defense mechanisms, opening the way to secondary bacterial infections (Folkerts et al., 1990; Hodgins et al., 2002). Some examples are: Parainfluenza-3 virus (Paramyxoviridae) induced pneumonia, Rotavirus (Reoviridae) and Coronavirus (Coronaviridae) induced neonatal diarrhea, bovine respiratory syncytial viral pneumonia, infectious bovine rhinotracheitis, ovine progressive pneumonia, contagious ecthyma in sheep and goats, infectious bronchitis in poultry and Avian Gumboro disease caused by the infectious bursal disease virus (Birnaviridae) (Chakraborty et al., 2014; Guy, 1998; Kapil \& Basaraba, 1997; Merck, 2015; Müller et al., 2003; Saif, 2010; TorresMedina et al., 1985).

\section{Phages and their derivatives as alternative antimicrobials}

Phages and phage proteins namely endolysins, exolysins and depolymerases can present several advantages as antimicrobials against bacterial infections that affect food-producing animals. Despite tested in vitro, these potential applications have also been tested in vivo (Table 2) with some promising results.

\section{Bacteriophages}

Phages are the most abundant entities in the biosphere, and can be isolated from several sources, including alimentary tract of humans and animals, food, soil, water, sewage and other environment niches. In fact, phages can be found in the same environments where their bacterial hosts exist (Bergh et al., 1989; Clokie et al., 2011).

Most phages are very specific, normally infecting single bacterial species or serovar groups, due to their attachment to specific receptors on bacterial surface before injecting their genetic material (Figure 1). Virulent phages follow a lytic cycle, multiplying inside the bacteria and lysing the cell to release new viruses. In contrast, temperate phages follow a lysogenic life cycle, integrating the bacterial genome without causing cell lysis, but still being able to switch to a lytic cycle under certain stimuli. For therapeutic or prophylactic applications, non-transducing virulent phages should be used to avoid the risk of virulence gene transduction and to take advantage of their replication capacity (Gill \& Hyman, 2010; Kutter et al., 2010; Kutter \& Sulakvelidze, 2005).

Phages have many advantages over antibiotics for therapeutic purposes, including: high specificity that reduces damage caused to the normal host microbiota; replication only at the site of infection; self-limiting and self-dosing capacity i.e. replication only when sensitive bacteria are present; and lower propensity to induce resistance, especially when using a phage cocktail (LocCarrillo \& Abedon, 2011; Örmälä \& Jalasvuori, 2013; Sulakvelidze et al., 2001).

Several in vivo studies support the use of phages as an intervention strategy for reducing bacterial infections in food-producing animals.

In poultry, promising results were obtained for phage therapy against Salmonella enterica serotypes Typhimurium and Enteritidis, which may cause disease especially in young chicks (Lima et al., 2016). The importance of using phage cocktails and administering high and multiple doses of phages was also demonstrated (Berchieri et al., 1991; Fiorentin et al., 2005; Sklar \& Joerger, 2001). Phages given both by coarse spray and in drinking water reduced Salmonella Enteritidis intestinal colonization of broiler chicks, showing that these means of phage administration are conceivable and can ease the application and establishment of phage biocontrol in an industrial environment (Borie et al., 2008). The combined treatment with phages and competitive exclusion products was also tested in birds, against Salmonella infections, showing synergistic effects (Borie et al., 2009). Other authors found that 
Table 2. Summary of in vivo studies evaluating bacteriophage and their derivatives against bacteria infecting food-producing animals.

\begin{tabular}{|c|c|c|c|c|c|}
\hline $\begin{array}{l}\text { Treatment } \\
\text { agent }\end{array}$ & $\begin{array}{l}\text { Animal } \\
\text { model }\end{array}$ & Pathogen & Delivery method & Output & Refs \\
\hline \multirow[t]{30}{*}{ Bacteriophages } & \multirow[t]{13}{*}{ Poultry } & \multirow[t]{6}{*}{ S. Enteritidis } & Oral gavage, cloacal & $\begin{array}{l}\text { Reduction in bacterial loads in cecal tonsils } \\
24 \mathrm{~h} \text { after treatment }\end{array}$ & $\begin{array}{l}\text { Andreatti Filho et al. } \\
\text { (2007) }\end{array}$ \\
\hline & & & $\begin{array}{l}\text { Aerosol spray, } \\
\text { drinking water }\end{array}$ & $\begin{array}{l}\text { Reduction of intestinal colonization by both } \\
\text { delivery methods }\end{array}$ & Borie et al. (2008) \\
\hline & & & Aerosol spray & $\begin{array}{l}\text { Reduction of } \approx 3 \log \text { CFU in cecal contents } \\
\text { when phages were combined with com- } \\
\text { petitive exclusion products }\end{array}$ & Borie et al. (2009) \\
\hline & & & Oral & Reduction of $3.5 \log$ CFU on cecal contents & Fiorentin et al. (2005) \\
\hline & & & Feed & $\begin{array}{l}\text { Prevention of horizontal bacterial transmis- } \\
\text { sion in the flock }\end{array}$ & Lim et al. (2012) \\
\hline & & & $\begin{array}{l}\text { Oral, feed, } \\
\text { drinking water }\end{array}$ & $\begin{array}{l}\text { Reduction of } 0.3-1.3 \log \text { CFU in cecal } \\
\text { contents }\end{array}$ & Sklar \& Joerger (2001) \\
\hline & & \multirow[t]{2}{*}{ S. Typhimurium } & Oral, feed & $\begin{array}{l}\text { High concentrations of phages reduced mor- } \\
\text { tality of birds }\end{array}$ & Berchieri et al. (1991) \\
\hline & & & Oral & $\begin{array}{l}\text { Reduction of Salmonella counts in cecum } \\
\text { and ileum; no clear synergism with com- } \\
\text { petitive exclusion products }\end{array}$ & Toro et al. (2005) \\
\hline & & \multirow[t]{5}{*}{ E. coli (APEC) } & Intramuscular & $\begin{array}{l}\text { Effective prevention and treatment of septi- } \\
\text { cemia and meningitis }\end{array}$ & Barrow et al. (1998) \\
\hline & & & $\begin{array}{l}\text { Aerosol spray, } \\
\text { intramuscular }\end{array}$ & $\begin{array}{l}\text { Reduction of bird mortality using intramuscu- } \\
\text { lar injection }\end{array}$ & Huff et al. (2003) \\
\hline & & & Intramuscular & $\begin{array}{l}\text { Total protection of birds using phage com- } \\
\text { bined with enrofloxacin }\end{array}$ & Huff et al. (2004) \\
\hline & & & Aerosol, drinking water & $\begin{array}{l}\text { Reduction of bird mortality using aerosol } \\
\text { administration }\end{array}$ & Huff et al. (2002) \\
\hline & & & Drinking water, spray & $\begin{array}{l}\text { Mortality reduced to levels below } 0.5 \% \text { in } \\
\text { naturally infected flocks }\end{array}$ & Oliveira et al. (2010) \\
\hline & \multirow[t]{8}{*}{ Swine } & \multirow[t]{5}{*}{ S. Typhimurium } & Oral & $\begin{array}{l}\text { Absence of clear evidences of intestinal } \\
\text { decrease of bacteria }\end{array}$ & Albino et al. (2014) \\
\hline & & & Oral gavage & Reduction of $>1.4 \log$ CFU in cecal contents & Callaway et al. (2010) \\
\hline & & & Oral, intramuscular & $\begin{array}{l}\text { Reduction of bacterial loads in pig tonsils ( } 4 \\
\text { log (FU) and cecum ( } 2 \text { log CFU) }\end{array}$ & Lee \& Harris (2001) \\
\hline & & & Oral gavage, feed & $\begin{array}{l}\text { Direct feeding of microencapsulated phages } \\
\text { led to a reduction of bacterial loads }\end{array}$ & Saez et al. (2011) \\
\hline & & & Oral gavage & $\begin{array}{l}\text { Microencapsulated phages led to a reduction } \\
\text { of bacterial counts (1-3 log CFU) }\end{array}$ & Wall et al. (2010) \\
\hline & & \multirow[t]{3}{*}{ E. coli (ETEC) } & Feed & $\begin{array}{l}\text { Reduction of } \approx 60 \% \text { of bacterial loads in } \\
\text { challenged pigs }\end{array}$ & Cha et al. (2012) \\
\hline & & & Oral & $\begin{array}{l}\text { Reduction of the duration and severity of } \\
\text { diarrhea }\end{array}$ & $\begin{array}{l}\text { Jamalludeen et al. } \\
\text { (2009) }\end{array}$ \\
\hline & & & Oral & $\begin{array}{l}\text { Efficient early treatment of ETEC diarrhea in } \\
\text { neonatal pigs }\end{array}$ & Smith \& Huggins (1983) \\
\hline & Cows & S. aureus & Intramammary & $\begin{array}{l}\text { Non-statistically significant cure rate of } \\
16.7 \%\end{array}$ & Gill et al. (2006a) \\
\hline & \multirow[t]{7}{*}{ Mice } & \multirow[t]{2}{*}{ E. faecium } & Intraperitoneal & $\begin{array}{l}\text { Higher phage doses rescue } 100 \% \text { of mice } \\
\text { from bacteremia }\end{array}$ & Biswas et al. (2002) \\
\hline & & & Intraperitoneal & $\begin{array}{l}\text { Efficient rescue of infected mice using low } \\
\text { phage titer }\end{array}$ & Uchiyama et al. (2008) \\
\hline & & \multirow[t]{3}{*}{$P$. aeruginosa } & Intraperitoneal & Protection of mice against infection & Soothill (1992) \\
\hline & & & Intraperitoneal & $100 \%$ rescue of bacteremic mice & $\begin{array}{l}\text { Vinodkumar et al. } \\
\text { (2008) }\end{array}$ \\
\hline & & & Intraperitoneal & $\begin{array}{l}\text { Survival rate dependent on the time of } \\
\text { administration and phage dose }\end{array}$ & Wang et al. (2006) \\
\hline & & \multirow[t]{2}{*}{ K. pneumonia } & Intraperitoneal & $\begin{array}{l}\text { Effective treatment of infection only with } \\
\text { early phage administration }\end{array}$ & Chhibber et al. (2008) \\
\hline & & & $\begin{array}{l}\text { Intraperitoneal, } \\
\text { intragastric }\end{array}$ & $\begin{array}{l}\text { Inhibition of infection by phages at low } \\
\text { doses; intraperitoneal treatment more effi- } \\
\text { cient than intragastric }\end{array}$ & Hung et al. (2011) \\
\hline & Hamster & C. difficile & Oral & Rescue most of the animals & Ramesh et al. (1999) \\
\hline \multirow[t]{6}{*}{ Endolysins } & \multirow[t]{6}{*}{ Mice } & S. pyogenes, MRSA & Intraperitoneal & Protection of $92 \%$ of mice from bacteremia & Gilmer et al. (2013) \\
\hline & & \multirow[t]{2}{*}{ S. pyogenes } & Intraperitoneal & $\begin{array}{l}\text { Protection of mice from death (90-95\%) in a } \\
\text { bacteremia model }\end{array}$ & Lood et al. (2014) \\
\hline & & & Oral, nasal & $\begin{array}{l}\text { Elimination of the pathogen in colonized } \\
\text { mice }\end{array}$ & Nelson et al. (2001) \\
\hline & & S. agalactiae & Intraperitoneal & Protection of $80 \%$ of mice from infection & Oechslin et al. (2013) \\
\hline & & $\begin{array}{l}\text { S. agalactiae, } \\
\text { S. dysgalactiae, } \\
\text { S. uberis }\end{array}$ & Intramammary & $\begin{array}{l}\text { Reduction of intramammary bacterial loads } \\
\quad(1.5-4.5 \mathrm{log})\end{array}$ & $\begin{array}{l}\text { Schmelcher et al. } \\
\text { (2015a) }\end{array}$ \\
\hline & & S. pneumoniae & $\begin{array}{l}\text { Aerosol } \\
\text { Intraperitoneal }\end{array}$ & $\begin{array}{l}\text { Reduction in mice mortality of } 80 \% \\
\text { Rescue of mice from death due to endolysins } \\
\text { synergism }\end{array}$ & $\begin{array}{l}\text { Doehn et al. (2013) } \\
\text { Jado et al. (2003) }\end{array}$ \\
\hline
\end{tabular}


Table 2. Continued

\begin{tabular}{|c|c|c|c|c|c|}
\hline $\begin{array}{l}\text { Treatment } \\
\text { agent }\end{array}$ & $\begin{array}{l}\text { Animal } \\
\text { model }\end{array}$ & Pathogen & Delivery method & Output & Refs \\
\hline & & & Intravenous, nasal, oral & $\begin{array}{l}\text { Reduction of bacterial loads in nasopharyn- } \\
\text { geal and bacteremia models; longer sur- } \\
\text { vival of animals }\end{array}$ & Loeffler et al. (2003) \\
\hline & & & Nasal, pharyngeal & $\begin{array}{l}\text { Reduction of bacterial loads to undetectable } \\
\text { levels }\end{array}$ & Loeffler et al. (2001) \\
\hline & & & Intraperitoneal & $\begin{array}{l}\text { Total protection of mice when administration } \\
\text { within } 24 \mathrm{~h} \text {; reduced protection in delayed } \\
\text { treatment ( } 42 \% \text { survival) }\end{array}$ & Witzenrath et al. (2009) \\
\hline & & MRSA & $\begin{array}{l}\text { Intraperitoneal } \\
\text { Intravenous }\end{array}$ & $\begin{array}{l}\text { Protection of mice from bacteremia } \\
\text { Increased survival rate and reduction of bac- } \\
\text { terial counts in the bloodstream }\end{array}$ & $\begin{array}{l}\text { Gu et al. (2011) } \\
\text { Jun et al. (2012) }\end{array}$ \\
\hline & & & Intraperitoneal, nasal & $\begin{array}{l}\text { Elimination of MRSA from the nares of mice } \\
\text { and protection against death }\end{array}$ & Rashel et al. (2007) \\
\hline & & & Intraperitoneal & $\begin{array}{l}100 \% \text { protection from death; no clinical signs } \\
\text { of disease }\end{array}$ & $\begin{array}{l}\text { Schmelcher et al. } \\
(2015 b)\end{array}$ \\
\hline & & B.anthracis & Intraperitoneal & Rescue of mice from fatal septicemia & Schuch et al. (2002) \\
\hline & Rats & S. pneumoniae & Intravenous & $\begin{array}{l}\text { Elimination of pneumococci causing endocar- } \\
\text { ditis from blood within } 30 \mathrm{~min} \text { with a } \\
\text { high-dose treatment }\end{array}$ & Entenza et al. (2005) \\
\hline & Rats, dogs & MRSA & Intravenous & $\begin{array}{l}\text { Absence of abnormal reactions to the } \\
\text { endolysin }\end{array}$ & Jun et al. (2014) \\
\hline \multirow[t]{8}{*}{$\begin{array}{l}\text { Engineered } \\
\text { endolysins }\end{array}$} & Mice & MRSA & Intraperitoneal & $\begin{array}{l}\text { Protection of mice from death with a syn- } \\
\text { ergy between the endolysin and oxacillin }\end{array}$ & Daniel et al. (2010) \\
\hline & & & Intraperitoneal & $100 \%$ protection of mice from death & Yang et al. (2014b) \\
\hline & & S. aureus & Topical & $\begin{array}{l}\text { Better performance ( } 3 \text { log CFU reduction) } \\
\text { than the antibiotic mupirocin }\end{array}$ & Pastagia et al. (2011) \\
\hline & & & Intramammary & $\begin{array}{l}\text { Reduction of } 3.36 \text { log CFU when combined } \\
\text { treatment with lysostaphin }\end{array}$ & $\begin{array}{l}\text { Schmelcher et al. } \\
\text { (2012b) }\end{array}$ \\
\hline & & S. pneumoniae & Intraperitoneal & $\begin{array}{l}50 \% \text { greater protection of mice compared to } \\
\text { the parental endolysin }\end{array}$ & $\begin{array}{l}\text { Díez-Martínez et al. } \\
\text { (2015) }\end{array}$ \\
\hline & Mice, rat & S. aureus & $\begin{array}{l}\text { Intranasal, } \\
\text { intramammary, } \\
\text { intramuscular }\end{array}$ & $\begin{array}{l}\text { Better activity than the parental protein in } \\
\text { models of nasal infection, mastitis and } \\
\text { osteomyelitis }\end{array}$ & Becker et al. (2016) \\
\hline & $\begin{array}{l}\text { Zebrafish } \\
\text { embryos }\end{array}$ & $\begin{array}{l}\text { S. pneumoniae, } \\
\text { S. pyogenes }\end{array}$ & Immersion & $\begin{array}{l}\text { Increased survival rate of } 95-99 \% \text {; combin- } \\
\text { ation with carvacrol was efficient in killing } \\
\text { Gram-negative bacteria }\end{array}$ & $\begin{array}{l}\text { Díez-Martínez et al. } \\
\text { (2013) }\end{array}$ \\
\hline & C. elegans & P. aeruginosa & Immersion & $\begin{array}{l}\text { Improved survival of nematodes with the } \\
\text { artilysin }(\approx 63 \%) \text { in relation to the native } \\
\text { endolysin }(\approx 40 \%)\end{array}$ & Briers et al. (2014a) \\
\hline Exolysins & Rat & MRSA & Intranasal & $\begin{array}{l}\text { Total decolonization of the nares of } 44.4 \% \\
\text { animals }\end{array}$ & Paul et al. (2011) \\
\hline \multirow[t]{2}{*}{ Depolymerases } & Poultry & Salmonella & Oral gavage & $\begin{array}{l}\text { Reduction of colonization and bacterial pene- } \\
\text { tration in internal organs }\end{array}$ & Waseh et al. (2010) \\
\hline & Rat & E. coli & Intraperitoneal & $\begin{array}{l}\text { Reduction of systemic infections and preven- } \\
\text { tion of death in at least } 80 \% \text { of infected } \\
\text { animals }\end{array}$ & Mushtaq et al. (2005) \\
\hline \multirow[t]{2}{*}{ Engineered phages } & Mice & E. coli & Intravenous & $\begin{array}{l}\text { Enhanced bacterial killing of phages when } \\
\text { combined with antibiotics }\end{array}$ & Lu \& Collins (2009) \\
\hline & & & Intraperitoneal & $\begin{array}{l}\text { Reduced phage toxicity and immunogenicity } \\
\text { and improved survival of animals }\end{array}$ & Matsuda et al. (2005) \\
\hline
\end{tabular}

although the combined treatment reduced the bacterial colonization, this reduction was at least as effective as phage treatment alone (Andreatti Filho et al., 2007; Toro et al., 2005). Phages were also effective as a prophylactic treatment for Salmonella Enteritidis. Lim et al. (2012) revealed that phages prepared as feed additives significantly prevented horizontal transmission of bacteria from infected to healthy chicks within the same flock, also reducing the environmental contamination level. In fact, $70 \%$ of the non-infected chickens treated with phage had no detectable intestinal Salmonella three weeks after treatment.

Regarding the control of the avian pathogenic Escherichia coli (APEC), Barrow et al. (1998) showed that phages were highly effective in both prevention and treatment of experimentally induced septicemia and meningitis. Huff et al. (2003) demonstrated that the efficacy of phage treatment is dependent on the route of administration, which in turn defines the phage titer reaching the site of infection. Phages given as an aerosol spray or intramuscular injection immediately after the $E$. coli challenge significantly reduced the mortality of birds but when the treatment was delayed, only the intramuscular injection was efficient. Also phages were more effective when administered as multiple intramuscular injections rather than a single dose. Phages given prophylactically as an aerosol significantly decreased the mortality of birds while when added to the drinking 


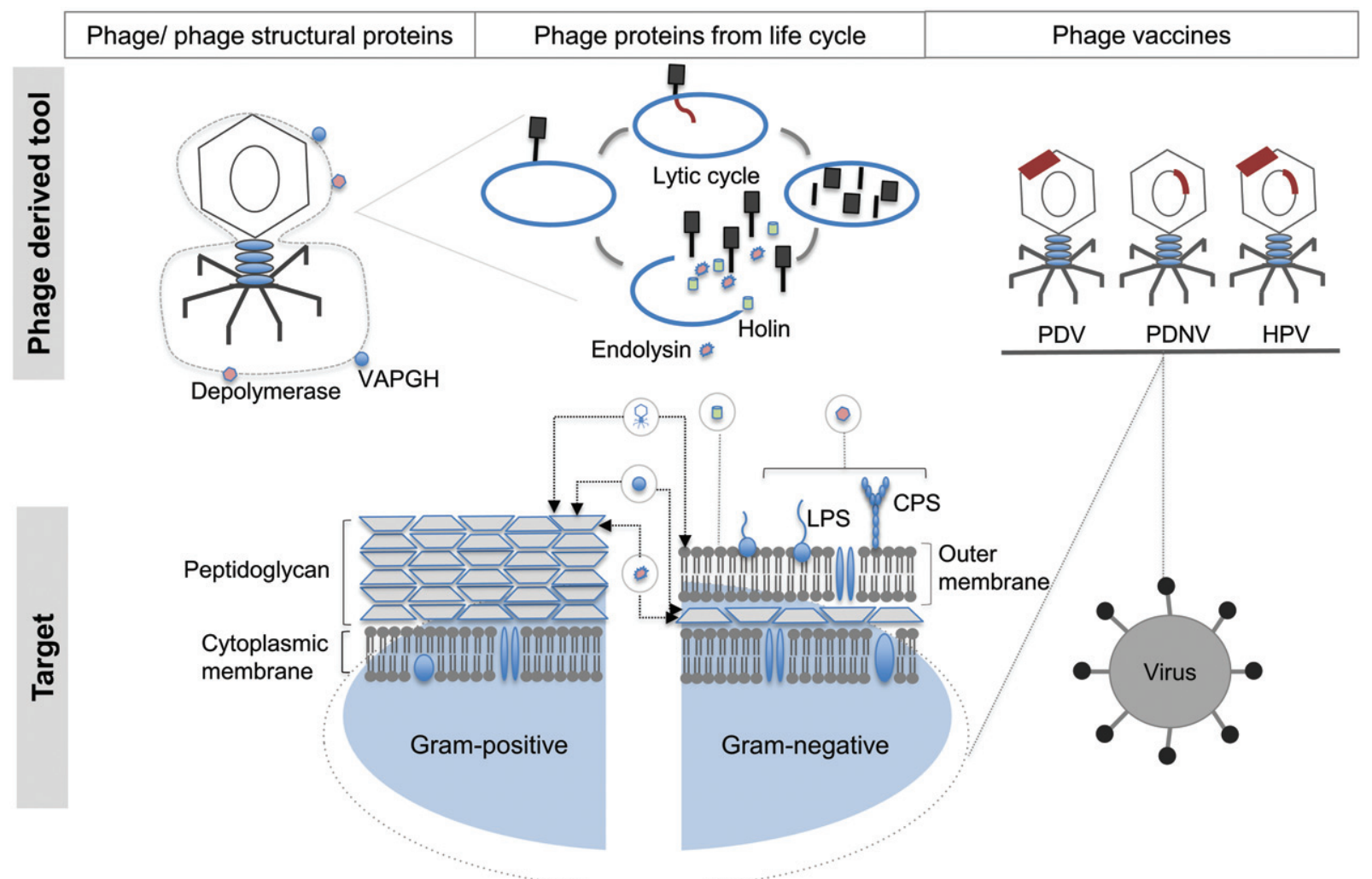

Figure 1. Schematic representation of the interactions between phages and phage-proteins (applied exogenously) and their respective targeted structures on the cell wall of Gram-positive and Gram-negative bacteria. Illustration of phages as antigen delivery vehicles against viruses and bacteria. CPS: capsular polysaccharides; LPS: lipopolysaccharides; PDV: phage display vaccine; PDNV: phage DNA vaccine; HPV: hybrid phage vaccine.

water provided no protection (Huff et al., 2002). The combination of the antibiotic enrofloxacin given in drinking water and the intramuscularly administered phage seemed to totally protect the challenged birds (Huff et al., 2004). In a more recent study, Oliveira et al. (2010) demonstrated the efficacy of a phage cocktail given orally and by spray in controlling $E$. coli infection in naturally infected flocks. The recorded mortality before treatment ranged between 0.7 and $7.8 \%$, depending on the sampled flocks. After phage administration, the mortality decreased to levels below $0.5 \%$.

There are relatively few studies in which phages have been used to control pathogens in swine. Smith \& Huggins (1983) performed the first study that demonstrated the efficacy of phages given at the onset of diarrhea (13-16h after infection) on the treatment of experimental Enterotoxigenic E. coli (ETEC) diarrhea in neonatal pigs. After the treatment, none of the pigs died, diarrhea was mild and a 3-log reduction was observed in fecal counts of ETEC. More recently, Jamalludeen et al. (2009) showed that phages given prophylactically or therapeutically to ETEC-infected weaned pigs decreased the duration and severity of diarrhea, without affecting the normal E. coli flora. Pigs were pre-treated orally with sodium bicarbonate to protect the phages from the acidity of the stomach and increase the numbers of viable phages entering the intestinal tract. Also a virulent phage, administered in feed one week before pigs were challenged with ETEC, led to significantly reduced bacterial loads (Cha et al., 2012).

Although a recent report on Salmonella control in pigs by Albino et al. (2014) described the absence of clear evidences in the intestinal decrease of Salmonella Typhimurium after phage treatment, other studies reported encouraging results, Lee \& Harris (2001) observed a significant reduction of Salmonella loads in pig tonsils (4-log reduction) and cecum (2-log reduction) after phage administration; other authors showed that administration of a phage cocktail given in feed or by gavage to pigs challenged with Salmonella Typhimurium, significantly reduced the bacterial load in the feces (Callaway et al., 2010; Saez et al., 2011; Wall et al., 2010).

Studies of phage efficacy to treat mastitis in lactating cows have also been performed but were not conclusive, requiring further experiments. For example, although an intramammary infusion of phage given to 
cows with pre-existing subclinical Staphylococcus aureus infection led to a cure rate of $16.7 \%$, the difference between this and the non-treated group was not statistically significant (Gill et al., 2006a). This can be due to phage inactivation in the udder due to milk proteins and fats since considerably lower rates of phages were found in the milk for up to $36 \mathrm{~h}$ post-treatment. Moreover, since $S$. aureus attaches to whey proteins and aggregates in milk this can limit phage binding (Gill et al., 2006b; O'Flaherty et al., 2005).

Other animal models have been used for phage therapy experiments, in which phages were efficient in the treatment of Enterococcus faecium (Biswas et al., 2002; Uchiyama et al., 2008), Pseudomonas aeruginosa (Soothill, 1992; Vinodkumar et al., 2008; Wang et al., 2006), Clostridium difficile (Ramesh et al., 1999) and Klebsiella pneumonia infections (Chhibber et al., 2008; Hung et al., 2011).

Overall, despite several in vivo experiments demonstrate that phages have potential as antimicrobials to control infections in food-producing animals, they still present limitations for therapeutic uses (Ly-Chatain, 2014). For example, although phages are less prone to cause resistance than antibiotics, bacteriophage insensitive mutants (BIMs) still occur, caused by the loss or mutation of the bacterial receptor (Hyman \& Abedon, 2010; Walmagh et al., 2012a), by the acquisition of restriction-modification systems or by the development of adaptive immunity through interfering clustered regularly interspaced short palindromic repeats (CRISPR) sequences (Hyman \& Abedon, 2010; Labrie et al., 2010). Other restrictions include the release of endotoxins caused by rapid lysis of a large number of bacteria that may cause allergic reactions (Drulis-Kawa et al., 2012; Lawrence, 2010), the possibility of inducing an in vivo anti-phage immune response, making it hard to sustain an effective phage concentration (Lawrence, 2010), and depending on the delivery system used, the achievement of an effective phage concentration at the site of infection (Abedon \& Thomas-Abedon, 2010).

In order to circumvent these limitations, several factors should be considered before phage application in vivo. These include the appropriate selection of phages; the use of phage cocktails with phages targeting different surface receptors of the same target pathogen, which can result in synergistic effects and reduction of the likelihood of emergence of bacterial resistance; and the optimization of the phage/bacteria ratio, timing and route of phage delivery, according to the target pathogen and food-producing animal.

Apart from the biological limitations, regulatory issues are still the major obstacle to phage therapy. The uniqueness of phages as protein-based, live-biological agents (Loc-Carrillo \& Abedon, 2011), offer a challenge to the regulatory agencies, which are struggling to find the best approach to regulate phage products (Keen, 2012). Although phages have been suggested as a "biological medicinal product" (Directive, 2001), requiring clinical trials for each phage strain, or as an "advanced therapy medicinal product" (Directive, 2003; Verbeken et al., 2007), with regulation based on manufacturing processes without mandatory clinical trials (Directive, 2003), no final decision has been taken so far.

\section{Phage-encoded proteins}

Recently, phage proteins, as endolysins, exolysins and depolymerases (Figure 1) have been explored as antimicrobial therapies, either alone or in combination with other agents.

Although some authors consider endolysins and exolysins in the category of depolymerases, we will exclude them from this class and mention each one separately.

\section{Endolysins}

Endolysins are enzymes produced by phages at the end of their replication cycle to digest the bacterial cell wall peptidoglycan (PG), allowing the release of phage progeny. Most endolysins show a modular organization, comprising a catalytic domain (CD) and a cell wall-binding domain (CBD). The CBD binds to the PG or another cell wall component, allowing the $C D$ to cleave a specific bond in the PG structure. Based on their catalytic activity site on the PG, endolysins can be muramidases, glucosaminidases, transglycosylases, amidases or endopeptidases (Schmelcher et al., 2012a).

These enzymes present several advantages as antimicrobials: they are, in general, very specific to the pathogen and thus do not disturb the normal microflora; so far, no resistance mechanisms or resistant phenotypes were detected after endolysins exposure, probably because these enzymes target essential structural components for bacterial viability and since they are applied exogenously they act on the outside of the cell, thereby avoiding a majority of possible resistance mechanisms (Fischetti, 2005; Loeffler et al., 2001, 2003; Nelson et al., 2001; Schmelcher et al., 2012a; Schuch et al., 2002); no signs of toxicity have been noticed after endolysins' treatment of systemic infections in mouse models (Jado et al., 2003; Loeffler et al., 2003; McCullers et al., 2007; Nelson et al., 2001); and the immune response induced by endolysins apparently does not neutralize their activity or prevent their use to treat systemic infections (Fischetti, 2005; Loeffler et al., 2003). 
Most of the work described with endolysins concerns Gram-positive bacteria, because Gram-negative bacteria have a highly impermeable outer membrane (OM) that limits the access of endolysins to the PG, when applied exogenously. Therefore, in order to lyse Gram-negative bacteria, most endolysins require physical treatment or chemical OM disruption agents, namely polycationic agents and chelators (Briers et al., 2008a, 2011; Walmagh et al., 2012b). Another option is to genetically engineer endolysins, as exemplified by the Artilysins (detailed below). Nevertheless, some endolysins have been reported to cross the OM and kill Gram-negative bacteria without chemical or physical treatment. Examples include the Salmonella phage endolysin SPN9CC (Lim et al., 2014), the Bacillus amyloliquefaciens phage endolysin Lys1521 (Morita et al., 2001a; Orito et al., 2004) and the Acinetobacter baumannii phage endolysin LysAB2 (Lai et al., 2011). Most of these enzymes have amphipathic or highly cationic regions that interact with the LPS to cross the OM (Lai et al., 2011; Morita et al., 2001b; Walmagh et al., 2012a).

Some phage endolysins have demonstrated capacity to kill some of the most prevalent Gram-positive pathogens such as $S$. aureus and Streptococcus uberis which cause mastitis in cows (Celia et al., 2008; Donovan et al., 2006; Horgan et al., 2009; Obeso et al., 2008) and Streptococcus suis which cause endocarditis and septicemia in pigs (Wang et al., 2009).

In animal models, endolysins have shown efficacy in the treatment and protection against a wide range of Gram-positive pathogens that infect animals and humans.

For Streptococcus pyogenes, oral administration of endolysin PlyC to colonized mice eliminated the pathogen within $2 \mathrm{~h}$ (Nelson et al., 2001). Also an intraperitoneal injection of the endolysin PlyPy (Lood et al., 2014) or PlySs2 (Gilmer et al., 2013) protected mice from death in a bacteremia model of $S$. pyogenes infection or a combined MRSA (Methicillin-resistant S. aureus) and S. pyogenes infection. For Streptococcus agalactiae, repeated intraperitoneal injections of PlySK1249 significantly protected mice from the infection (Oechslin et al., 2013). In a mouse model of bovine mastitis, intramammary infusions of endolysins $\lambda \mathrm{SA} 2$ and $\mathrm{B} 30$ led to a significantly reduction on the intramammary concentrations of the S. agalactiae, Streptococcus dysgalactiae and Streptococcus uberis (except for B30 vs. S. dysgalactiae) (Schmelcher et al., 2015a).

On Streptococcus pneumoniae, endolysins showed potential to control and treat mucosal and systemic infections. Several methods of delivering endolysin Cpl1 to infected mouse models were tested with different outcomes. When Cpl-1 was given intravenously, the bacterial loads were reduced to undetected levels within $15 \mathrm{~min}$. Nevertheless, the treated animals died from the infection, possibly due to the relatively short half-life of Cpl-1 in the blood (15-20 min), which indicates that additional doses of $\mathrm{Cpl}-1$ could be needed to completely eradicate $S$. pneumoniae (Loeffler et al., 2003). Endolysins Cpl-1 and Pal applied intraperitoneally to $S$. pneumoniae infected mice, acted synergistically and rescued mice from death (Jado et al., 2003). Also Witzenrath et al. (2009) showed that when applying endolysin Cpl-1 24h after bacterial challenge with $S$. pneumoniae, mice were fully protected. However, when treatment was delayed for 2 days, the survival rate reduced to $42 \%$. Cpl-1 was also given by aerosol to infected mice after the onset of pneumonia and reduced the mortality by $80 \%$ (Doehn et al., 2013). Cpl1 was also efficient in the elimination and prevention of acquired S. pneumoniae endocarditis in rats (Entenza et al., 2005). The application of the endolysins Pal or Cpl-1 has successfully eliminated $S$. pneumoniae from the nares of mice (Loeffler et al., 2001, 2003).

Phage endolysins have also been shown to be powerful therapeutic agents against multidrug-resistant S. aureus infections and protected mice from death when administered intraperitoneally (Gu et al., 2011; Rashel et al., 2007; Schmelcher et al., 2015b). An endolysin-based pre-formulation (SAL200), administered as an intravenous injection in a mouse model of MRSA infection, reduced Staphylococcus counts in the bloodstream and prolonged survival of mice (Jun et al., 2012). In a preclinical study with rats and dogs, repeated intravenous treatment with SAL200 did not induce signs of toxicity (Jun et al., 2014). Regarding Bacillus anthracis, endolysin PlyG, applied as an intraperitoneal injection, rescued mice from fatal septicemia (Schuch et al., 2002).

Phage endolysins have also shown to act synergistically with other endolysins (Jado et al., 2003; Loeffler \& Fischetti, 2003), bacteriolytic enzymes such as lysostaphin (Becker et al., 2008; Schmelcher et al., 2012b) and antibiotics (Daniel et al., 2010; Djurkovic et al., 2005; Rodríguez-Cerrato et al., 2007).

Holins are proteins encoded by phages during the late phase of the lytic cycle and are involved in the permeabilization of the membrane, allowing endolysins to cross into the periplasm and degrade the PG (Wang et al., 2000). The combined use of holins and endolysins might be a promising strategy for antimicrobial therapy. Shi et al. (2012) combined the holin HolSMP and the endolysin LySMP, resulting in an extended spectrum of the endolysin against strains of multidrug-resistant $S$. suis and S. aureus.

Due to their modular structure, endolysins can be genetically engineered to display desired functional 
properties such as extended host spectra, improved lytic activity, solubility and ability to infect Gram-negative bacteria (Fernandes et al., 2012; Yang et al., 2014a).

The modular engineering of endolysins involves the shuffling of natural lysins domains, generating chimeric lysins (or "chimeolysins"), or the fusion of a natural lysin or part of its domain with another component from a peptide or a protein (artificial lysins or "artilysins").

Recent studies demonstrated that chimeolysins have increased lytic activity and a host range broader than natural enzymes (Becker et al., 2009; Dong et al., 2015; Mao et al., 2013; Schmelcher et al., 2011).

In vivo studies proved the efficacy of treatment with genetically modified endolysins in animal models against human and animal infections.

The chimeolysins $\mathrm{ClyH}$ and ClyS when given as an intraperitoneal injection, protected mice from death by MRSA (Daniel et al., 2010; Yang et al., 2014b). The chimeolysin ClyS, when applied topically, performed better than the antibiotic muciporin in a mouse model of skin colonization/infection with S. aureus (Pastagia et al., 2011). An engineered triple-acting staphylolytic endolysin reduced colonization by $S$. aureus in a rat nasal colonization model, surpassing the efficacy of either parental protein. When this protein was modified with a transduction domain and tested in a mouse model of mastitis, it demonstrated significantly improvement on the ability to kill intracellular S. aureus (Becker et al., 2016). Also, an intramammary infusion of the chimeric endolysins $\lambda \mathrm{SA} 2-\mathrm{E}-\mathrm{Lyso}-\mathrm{SH} 3 \mathrm{~b}$ or $\lambda \mathrm{SA2}$-E-LysK-SH3b reduced $S$. aureus loads by 0.63 or 0.81 log units in a mouse model of mastites. When $\lambda \mathrm{SA} 2-\mathrm{E}-\mathrm{Ly}$ sK-SH3b was administered in combination with lysostaphin, a 3.36 log reduction was observed in the Staphylococcus loads (Schmelcher et al., 2012b).

A single dose of chimeolysin Cpl-7S significantly increased the survival rate of infected zebrafish embryos for S. pneumoniae and S. pyogenes (Díez-Martínez et al., 2013). Similarly, a single intraperitoneal injection of the chimeric protein Cpl-711, administrated $1 \mathrm{~h}$ after $S$. pneumoniae challenge, resulted in about $50 \%$ greater protection of mice than with the parental endolysin (Díez-Martínez et al., 2015).

As stated above, the major drawback of endolysins is their limited action against Gram-negative bacteria. This was overcome by engineering these enzymes as outer membrane-penetrating endolysins (Artilysins). Briers et al. (2014a) fused endolysins with different LPS-destabilizing peptides with polycationic, hydrophobic and amphipathic properties, enabling the enzymes to pass the $\mathrm{OM}$ and become active against Gram-negative bacteria. For example, the artilysin LoGT-001 was able to kill $P$. aeruginosa ( $\geq 5.50-\mathrm{log}), A$. baumannii $(5.18-\mathrm{log}), E$. coli $(2.41-\log )$ and S. Typhimurium (1.52-log) cells in $30 \mathrm{~min}$. LoGT-001 was tested in vivo in a Caenorhabditis elegans infection model with $P$. aeruginosa leading to a survival of $63 \pm 4 \%$ nematodes 5 days postinfection, while $90 \%$ of the animals that did not receive the Artilysin were killed. Recently, the construction of artilysins by fusing endolysins with antimicrobial peptides (AMPs) which have a self-promoted uptake mechanism across the OM was reported. Artilysins Art-085 and Art175 , which result from the fusion of an AMP sheep myeloid 29-amino acid (SMAP-29) peptide with the KZ144 endolysin, were able to cross the $\mathrm{OM}$ and reduce $P$. aeruginosa loads by 5-log in vitro (Briers et al., 2014b). In two case studies of dogs with otitis, the treatment with Art-085 was able to cure the animals from an infection by $P$. aeruginosa, which was not eliminated with standard antibiotics (Briers \& Lavigne, 2015).

\section{Exolysins or VAPGHs (virion-associated peptidogly- can hydrolases)}

Exolysins are another type of peptidoglycan enzymes encoded by some phages that, in contrast to endolysins, are present as part of the phage structure and participate in the first step of phage infection. VAPGHs degrade the peptidoglycan, enabling phages to reach the bacterial cytoplasmic membrane thus facilitating DNA injection into the host cell (Letellier et al., 1999). These proteins have been identified in phages infecting both Gram-positive and Gram-negative bacteria (Moak \& Molineux, 2004). Few VAPGHs have so far been analyzed, however, some studies show their antimicrobial activity when applied exogenously (Rashel et al., 2008; Rodríguez et al., 2011; Takáč \& Bläsi, 2005).

Like endolysins, VAPGHs have limited activity against Gram-negative bacteria due to the presence of an OM. However, some VAPGH have shown activity in vitro against Gram-negative bacteria when used with OM destabilizing conditions (Briers et al., 2008b; Caldentey \& Bamford, 1992; Lavigne et al., 2004).

VAPGHs present several advantages as antimicrobials: high thermostability and specificity (Lavigne et al., 2004), a low probability of bacterial resistance, and a modular organization that allows the construction of chimeric proteins with multiple domains to improve their antimicrobial activity.

Rodríguez-Rubio et al. (2012) discovered that truncated derivatives and fusion proteins of $\mathrm{HydH} 5$, a VAPGH from a $S$. aureus phage, exhibited high lytic activity against $S$. aureus when compared with the parental enzyme and displayed antimicrobial synergy with the endolysin LysH5. These proteins are promising agents against $S$. aureus, which cause bovine mastitis, 
since they were able to prevent its growth in milk (Rodríguez-Rubio et al., 2013). The chimeric protein P16-17, composed of the $\mathrm{N}$-terminal endopeptidase domain of endolysin Lys 16 and the C-terminal CBD of VAPGH P17, exhibited antimicrobial activity towards $S$. aureus and augmented the antimicrobial efficacy of the antibiotic gentamicin (Manoharadas et al., 2009). Similarly, the chimeric exolysin P128, composed by a tail-associated muralytic enzyme (TAME) from phage $K$ and a lysostaphin $\mathrm{SH} 3$ cell wall-targeting domain, showed a potent anti-staphylococcal activity in vitro. Moreover, when tested in a mouse infection model, P128 reduced MRSA colonization of rat nares by 2-log (Paul et al., 2011).

\section{Depolymerases}

Depolymerases are phage-encoded proteins that have glycanase-like activity and digest the polysaccharides of the bacterial cell wall, namely lipopolysaccharides (LPS) and capsular polysaccharides (CPS).

Although some of these proteins are soluble and generated during host cell lysis, the majority of the described phage depolymerases are structural proteins, facilitating phage infection (Oliveira et al., 2013).

According to their mode of action, phage depolymerases can be hydrolases if they catalyze the hydrolysis of glycosidic bonds, or lyases if they cleave $(1,4)$ glycosidic bonds by a $\beta$-elimination mechanism (Oliveira et al., 2013).

There are still few in vivo studies in which depolymerases were applied. Mushtaq et al. (2005) showed that a depolymerase with endosialidase activity (endoE) administered to rats reduced systemic $E$. coli infections, suggesting that the degradation of the bacterial CPS decreased its virulence and sensitized cells to host defenses. Waseh et al. (2010) also demonstrated that the oral administration of a tail spike protein with endorhamnosidase activity reduced Salmonella colonization in chickens. This may be attributed to the binding of the protein to the O-antigen hence compromising the structure of LPS and, consequently, reducing bacterial motility and infectivity.

\section{Phage-derived vaccines}

Although the importance of innovation on therapeutic approaches is irrefutable, preventing diseases is always preferable to treatment. Vaccines are one of the most important immunomodulators, acting by stimulation of the body's immune system to recognize the agent as foreign, enabling infection control. Therefore, the use of vaccines may decrease the need for antibiotics, contributing to improve health, welfare and production yields in animal husbandry (Prisco \& De Berardinis, 2012).

Conventionally, a vaccine contains the causative agent of the disease, genetically engineered microbes, vectored antigen formulations or naked DNA (DNA vaccines).

Recently, phages are also considered as vaccinedelivery vehicles against bacterial or viral infections, as they possess numerous intrinsic characteristics making them promising tools in this field. Presently, two distinct approaches are proposed, either used independently or combined: phage display vaccines and phage DNA vaccines (Clark \& March, 2004a) (Figure 1).

In phage display vaccines, specific proteins or peptides from the antigens of interest are engineered to be expressed on the phage surface, leading to an immunogenic response (Clark \& March, 2006). The conception of these vaccines relies on the phage display technology, which allows the fusion of the DNA coding a polypeptide with phage structural protein genes, enabling the expression of the former protein on the phage surface (Sidhu, 2000; Smith, 1985). Some phages were already identified as advantageous for this purpose, as T4, T7, lambda phages and the filamentous M13. The T4 phage allows the display of large peptides on its capsid proteins, Soc (small outer capsid protein; 960 copies per particle) and Hoc (highly antigenic outer capsid protein; 160 copies per particle) (Li et al., 2006). In the T7 phage, the fusion proteins are displayed on protein 10B (5-15 copies) of the major phage capsid (gp10), and in the lambda phage both the tail protein gpV (at least 5 copies) and the head protein gpD (405-420 copies) have been used for displaying foreign peptides (Sundell \& Ivarsson, 2014). The M13 phage is a highly versatile system as distinct coat proteins can be used for peptide display. Commonly, the plll protein is used for low valency display ( $1-5$ copies per phage) and the pVIII for high valency display (up to 1000 copies per phage) (Sundell \& Ivarsson, 2014).

In phage DNA vaccines, phages are used as vehicles for the delivery of the foreign antigen DNA incorporated into the phage genome, under the control of strong eukaryotic promoters. Lambda phage vectors are commonly used for this purpose (Clark \& March, 2004a). Inside the animal organism, the antigen gene will be expressed in targeted cells from the immune system (Clark \& March, 2006), originating an immune response.

Overall, vaccines lead to humoral (antibody-dependent) and/or cellular (cell-dependent) immune responses through the combined role of different groups of cells: antigen-presenting cells (APC), which capture and display antigens to another group, the regulatory T- 
lymphocytes (Helper cells - HC), which when activated induce the activity of the effector cells (EC) that will accomplish the elimination of antigens (Siegrist, 2012).

The humoral response is mediated by B-lymphocytes (APC), and might be triggered by immunogenic antigens, as the peptides displayed in the surface of phage display vaccines. After the intervention of $\mathrm{HC}$ and $\mathrm{EC}$, antibodies will be released, and memory B-cells will remain for subsequent exposures. In the cellular immune response and in the case of a DNA phage vaccine, macrophages or dendritic cells (APC) will translate the foreign antigen DNA into peptides, inducing through $\mathrm{HC}$ the activation of phagocytic cells and cytotoxic T-lymphocytes (remain as memory cells) that will destroy the antigen (Figure 2).

Recent studies reported the possibility of producing a hybrid phage vaccine, combining the two versions of phage vaccines. Here, the DNA vaccine is enclosed within the phage particle and a phage-display variant of the same antigen is present on the phage surface, with specific binding affinity to the APC (Clark \& March,
2006). This combination has the advantage of delivering the antigen gene directly to the immunoreactive cells, efficiently targeting both humoral and cellular immune systems (Clark \& March, 2006; Haq et al., 2012; Zanghi et al., 2007) and, consequently, enhance the vaccine specificity and the effectiveness of the immune response.

In broad terms, phage vaccines have several advantages relatively to the conventional ones (Clark \& March, 2004a; Olofsson et al., 2008). Phage vaccines can be economically manufactured, due to the possibility of rapidly obtaining high phage titers on relatively inexpensive media, with straightforward purification steps. These features allow the attainment of sufficient quantities of vaccines against new pathogens as, for example, during disease outbreaks. Moreover, the lack of pathogenicity of the phage particles in animals and their increased chemical stability are also important when safety issues are concerned. Also, phages enclose natural adjuvant properties that confer them a real advantage in relation to conventional vaccines. Adjuvants are

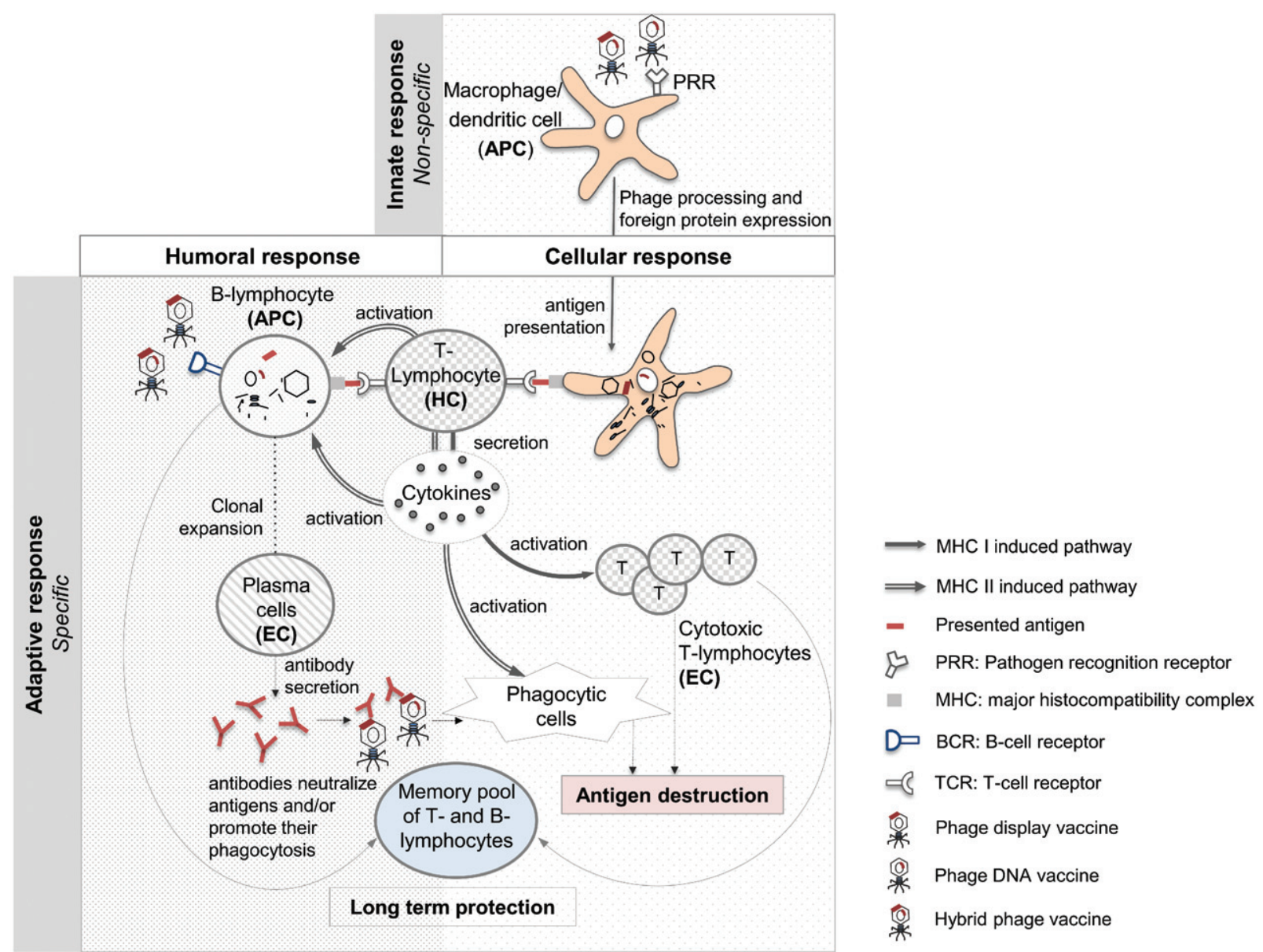

Figure 2. Schematic example of the innate and adaptive (humoral and cellular) immune system response activated by different types of phage vaccines: phage display vaccines, phage DNA vaccines and hybrid phage vaccines. APC: antigen presenting cells; EC: effector cells; HC: helping cells. 
compounds that enhance the specific immune response against co-inoculated antigens, particularly by stimulating antibodies production. This feature is related to the presence of unmethylated CpG dinucleotides (cytosinephosphodiester linked-guanine), naturally found in the phage genome and able to be recognized by the innate immune cells through protein receptors (Toll-like receptors) (Adhya et al., 2014; Krieg et al., 1995; Mason et al., 2005).

Particularly for phage DNA vaccines, apart from the already mentioned manufacturing advantages, the possibility of ensuring the absence of antibiotic resistance genes, the large cloning capacity of the phage vector (e.g. 15-20 kb can be used in standard lambda vector), the potential for oral delivery, and the natural protection offered by the phage capsid to DNA against environmental degradation (contrarily to naked DNA vaccines) are some other relevant advantages (Clark \& March, 2004a). Additionally, enclosure of foreign DNA in a phage that acts as a particulate antigen, enables both the induction of antibody production (humoral response) and the activation of the cellular immune response (Gaubin et al., 2003), enhancing the vaccine efficacy.

However, there are still few studies in which phage particles displaying antigenic proteins have been used as vaccines in animal models (Bazan et al., 2012). An example of an effective phage display vaccine was reported by Hayes et al. (2010). In this work, immunodominant regions of the porcine circovirus were successfully displayed in lambda phage capsid, and neutralizing antibodies were produced against this infection in pigs, stimulating both cellular and humoral immune responses.

Wu et al. (2007) used the phage T4 HOC, SOC dual site display system, hence leading to a simultaneous display of two different antigens on the T4 capsid surface. The resultant phages were administered to mice as a vaccine against classical swine fever virus (CSFV). The results of animals' immune response revealed that the antibody titers elicited in mice by the T4 phage-CSFV recombinants were significantly higher than those obtained by immunization with recombinant antigens produced by conventional expression in recombinant $E$. coli cells. In another work, an orally delivered foot-andmouth disease virus (FMDV) vaccine, in which the capsid protein was displayed on the surface of T4 phage particles, conferred mice $100 \%$ protection against a lethal dose of a FMDV-O serotype. Moreover, pigs immunized with this vaccine were protected when animals were cohoused with FMDV-infected pigs (Ren et al., 2008).

Hashemi et al. (2012) concluded that the genetic fusion of a domain of influenza $A$ virus (M2 protein) with T7 phage-based particles effectively protected mice against this disease, even without adjuvant, as the defense cells' secretion frequency was comparable to those elicited by the peptide itself, emulsified in the conventional adjuvant.

Hashiguchi et al. (2010) described a strong lgG primary response in mice and the induction of long-lasting antibody response with a single immunization with M13 phage injected intraperitoneally, suggesting this phage as a potential vaccine carrier.

Regarding phage DNA vaccines, there are few studies designed for food-producing animals' infections, and most target humans' pathogens (Clark \& March, 2004a, 2004b). Ou et al. (2013) tested a lambda phage-mediated DNA vaccine against Chlamydia abortus in piglets and proved its capacity of inducing antigen-specific cellular and humoral immune responses providing protective immunity.

\section{Genetically-modified phages}

Recent developments on genetic tools are creating new opportunities for the modification of phage genomes to improve their properties for therapeutic and prophylactic applications (Nobrega et al., 2015; Pires et al., 2016). These tools include bacteriophage recombineering of electroporated DNA (BRED), yeast artificial chromosome (YAC) and the CRISPR-Cas system.

BRED (Marinelli et al., 2008) uses bacterial overexpression of plasmid-encoded recombination genes (e.g. the lambda Red system) to enhance the frequency of homologous recombination between phage DNA and DNA substrate after electroporation (Fehér et al., 2012; Marinelli et al., 2012). YAC (Lu et al., 2013) consists on the insertion of the whole phage genome inside a YAC vector by homologous recombination, creating a recombinant YAC that is propagated in the vector host where the phage genome can be modified by yeast recombineering. The modified YAC may then be inserted into bacteria for phage replication. The CRISPR-Cas system is the most recent tool for the genetic modification of phages. This system is involved in the protection of microbial cells from DNA invasion and comprises an array of repeats and spacers. Transcribed spacers guide specific proteins to the target DNA (e.g. phage DNA), and cleave it. The break can then be repaired by homologous recombination if a mutated template is provided (Kiro et al., 2014). Compared with other methods, CRISPR-Cas provides higher percentages of mutated phages, simplifying selection and recovery (Kiro et al., 2014; Martel \& Moineau, 2014).

There are several examples of the use of these techniques for genetic manipulation of phage 
genomes with therapeutic interest. One of the main goals is the extension of phage host range, which has been achieved, for example, by designing phage T7 for the expression of an endosialidase degradative of the $\mathrm{K} 1$ capsule that is present in some $E$. coli strains (Scholl et al., 2005) or by replacing the host binding genes of phage T2 for those of phage PP01 (Yoichi et al., 2005). It is also important to reduce phage toxicity and immunogenicity that may hinder therapeutic efficacy and cause adverse side effects. This can be achieved by developing lysis-deficient and non-replicating phages, avoiding toxin release during bacterial lysis in vivo (Hagens et al., 2004; Matsuda et al., 2005). Some manipulations have been performed to enhance phage survival after administration, including the introduction of a single specific mutation on a phage genome that resulted in the generation of long-circulating phages (Vitiello et al., 2005). It is also possible to improve phage activity against biofilms, as demonstrated by Lu \& Collins (2007) with the engineering of T7 for the expression of dispersin B, a biofilm-degrading enzyme, which resulted in a 100,000 fold increased efficiency. Genetic modification has also been used to enhance bacterial killing of phages when combined with antibiotics, for example by engineering lysogenic phages to overexpress proteins that target specific nonessential gene networks (Lu \& Collins, 2009).

\section{Future perspectives}

In an era of increasing emergence of multi-drug resistant pathogens and a scarcity of new antimicrobials, together with the restrictions imposed by European Union to the use of traditional antibiotics in animal husbandry, there is an urgent need to find antimicrobial alternatives.

Phage-based solutions presented herein have potential as therapeutic or prophylactic tools for application in livestock production. In fact, there is compelling evidence from the in vitro and in vivo studies of the potential of phages against an array of Gram-positive and Gram-negative bacterial pathogens that infect food-producing animals.

Phage particles pose several intrinsic characteristics that make them profitable for the development of products to treat or prevent diseases, as well as for the design of vaccine-delivery platforms. The natural stability, easy production and purification of phages provides cheaper and large-scale capacity for the manufacturing of these products. However, the acceptance of phages for this purpose will depend on its efficacy, safety and cost compared with other interventions. Therefore, a more detailed biologic and genetic characterization of phages is mandatory to avoid undesirable outcomes. These include a bacterial adaptive response to phage infection by the generation of BIMs or even an increase in bacterial virulence when phages transfer virulent genes such as toxin and antibiotic-resistant genes among bacteria. Moreover, the efficacy of phage therapy requires an appropriate choice of phages, dosage, delivery route and timing of administration, which should be adapted according to the pathogen and animal targeted.

From another point of view, the development of synthetic biology and molecular tools enables the construction of genetically-modified phages with valuable features such as extension of the host range, reduced toxicity and immunogenicity and enhanced survival after administration. Moreover, it also allows to use phage proteins, namely endolysins and exolysins, that present broader antibacterial spectrum, lower immunogenicity and low probability of bacterial resistance and thus can be considered as potentially valuable therapeutics to fight infections. Until now, these enzymes target mainly Gram-positive bacteria but further screening for new ones or engineering these enzymes combined with other proteins, as OM transporters or holins to target Gram-negative bacteria is ongoing, and it is expected to increase the value of phage enzymes as therapeutics for both human and animal health.

Despite all the reported evidences of success on using phage-derived solutions presented herein, the use of these antimicrobials to completely substitute antibiotics is not a straightforward or probable approach, mainly because antibiotics have several uses in the animal production, such as prevention and treatment of diseases and promotion of growth. Therefore, the combination of phage-based alternatives with the traditional ones, when used rationally, may be a path to follow.

Another important issue regarding animal production is the scarce number of studies directed for veterinary purposes. The urgent requisite of decreasing antibiotic use in food-production animals should encourage researchers to design experiments specifically for animal applications.

Furthermore, it is urgent that regulatory bodies establish protocols for phage product regulation, so that the use of phages in veterinary applications does not remain stalled by regulatory issues. Regulatory bodies such as the US Food and Drug Administration (FDA), the US Department of Agriculture (USDA) and 
the European Medicines Agency (EMEA) have shown some flexibility in approving the use of phages for control of several problematic pathogens.

Presently, there are already several companies developing phage products that can be used in Veterinary Medicine. These comprise BioPhage-PA, a topical phage product for chronic otitis against antibiotic-resistant $P$. aeruginosa that has already completed the phase $\mathrm{I} / \mathrm{II}$ of clinical trials, and Viridax ${ }^{\mathrm{TM}}$, for the treatment of respiratory, systemic and topical infections of $S$. aureus and other Staphylococcal species. Other products were already approved and are being commercialized. These include: feed additives, such as BioTector to control Salmonella in poultry; products for direct food applications, such as ListShield ${ }^{\mathrm{TM}}$ and Listex $\mathrm{P}-100^{\mathrm{TM}}$ for Listeria monocytogenes, EcoShield ${ }^{\mathrm{TM}}$ for $E$. coli 0157:H7, Salmonelex ${ }^{\mathrm{TM}}$ and SalmoFresh ${ }^{\mathrm{TM}}$ for Salmonella; and products for agricultural use, such as AgriPhage ${ }^{T M} M$ to control Xanthomonas campestris or Pseudomonas syringae on crops. Omnilytics ${ }^{\mathrm{TM}} \mathrm{M}$ also has some approved products that target Salmonella and E. coli 0157:H7 on cattle hides and poultry prior to slaughter.

Overall, the continuous research of the already existing antibiotic alternatives and the development of safe and efficient new ones, is needed to combat the threat of antibiotic resistant pathogens and to ensure sustainable animal and human welfare.

\section{Disclosure statement}

The authors report no declarations of interest.

\section{Funding}

This study was supported by the Portuguese Foundation for Science and Technology (FCT) under the scope of the strategic funding of UID/BIO/04469/2013 unit and COMPETE 2020 (POCl-01-0145-FEDER-006684), and the Project RECl/ BBB-EBI/0179/2012 (FCOMP-01-0124-FEDER-027462 and PTDC/CVT-EPI/4008/2014). The authors were supported by the FCT grants: SFRH/BPD/69356/2010, SFRH/BPD/79365/2011 and SFRH/BPD/94648/2013.

\section{ORCID}

Carla Carvalho (D) http://orcid.org/0000-0002-9345-6546

\section{References}

Aarestrup FM, Bager F, Jensen NE, et al. (1998). Surveillance of antimicrobial resistance in bacteria isolated from food animals to antimicrobial growth promoters and related therapeutic agents in Denmark. Apmis 106:606-22.

Abedon S, Thomas-Abedon C. (2010). Phage therapy pharmacology. Curr Pharm Biotechnol 11:28-47.
Adhya S, Merril CR, Biswas B. (2014). Therapeutic and prophylactic applications of bacteriophage components in modern medicine. Cold Spring Harb Perspect Med 4:a012518.

Albino LAA, Rostagno MH, Húngaro HM, Mendonça RCS. (2014). Isolation, characterization, and application of bacteriophages for Salmonella spp. biocontrol in pigs. Foodborne Pathog Dis 11:602-9.

Andreatti Filho RL, Higgins JP, Higgins SE, et al. (2007). Ability of bacteriophages isolated from different sources to reduce Salmonella enterica serovar Enteritidis in vitro and in vivo. Poult Sci 86:1904-9.

Barrow P, Lovell M, Berchieri A. (1998). Use of lytic bacteriophage for control of experimental Escherichia coli septicemia and meningitis in chickens and calves. Clin Diagn Lab Immunol 5:294-98.

Bazan J, Całkosiński I, Gamian A. (2012). Phage display - a powerful technique for immunotherapy: 2. Vaccine delivery. Hum Vaccin Immunother 8:1829-35.

Becker SC, Foster-Frey J, Donovan DM. (2008). The phage K lytic enzyme LysK and lysostaphin act synergistically to kill MRSA. FEMS Microbiol Lett 287:185-91.

Becker SC, Foster-Frey J, Stodola AJ, et al. (2009). Differentially conserved staphylococcal SH3b_5 cell wall binding domains confer increased staphylolytic and streptolytic activity to a streptococcal prophage endolysin domain. Gene 443:32-41.

Becker SC, Roach DR, Chauhan VS, et al. (2016). Triple-acting lytic enzyme treatment of drug-resistant and intracellular Staphylococcus aureus. Sci Rep 6:25063.

Berchieri A, Lovell M, Barrow P. (1991). The activity in the chicken alimentary tract of bacteriophages lytic for Salmonella typhimurium. Res Microbiol 142:541-49.

Bergh O, Borsheim KY, Bratbak G, Heldal M. (1989). High abundance of viruses found in aquatic environments. Nature 340:467-68.

Biswas B, Adhya S, Washart P, et al. (2002). Bacteriophage therapy rescues mice bacteremic from a clinical isolate of vancomycin-resistant Enterococcus faecium. Infect Immun 70:204-10.

Borie C, Albala I, Sánchez P, et al. (2008). Bacteriophage treatment reduces Salmonella colonization of infected chickens. Avian Dis 52:64-67.

Borie C, Sánchez M, Navarro C, et al. (2009). Aerosol spray treatment with bacteriophages and competitive exclusion reduces Salmonella enteritidis infection in chickens. Avian Dis 53:250-54.

Bradley A, Breen J, Payne B, et al. (2015). An investigation of the efficacy of a polyvalent mastitis vaccine using different vaccination regimens under field conditions in the United Kingdom. J Dairy Sci 98:1706-20.

Briers Y, Cornelissen A, Aertsen A, et al. (2008a). Analysis of outer membrane permeability of Pseudomonas aeruginosa and bactericidal activity of endolysins KZ144 and EL188 under high hydrostatic pressure. FEMS Microbiol Lett 280:113-19.

Briers Y, Miroshnikov K, Chertkov O, et al. (2008b). The structural peptidoglycan hydrolase gp181 of bacteriophage phiKZ. Biochem Biophys Res Commun 374:747-51.

Briers Y, Lavigne R. (2015). Breaking barriers: expansion of the use of endolysins as novel antibacterials against Gramnegative bacteria. Future Microbiol 10:377-90. 
Briers Y, Walmagh M, Lavigne R. (2011). Use of bacteriophage endolysin EL188 and outer membrane permeabilizers against Pseudomonas aeruginosa. J Appl Microbiol 110:778-85

Briers Y, Walmagh M, Van Puyenbroeck V, et al. (2014a). Engineered endolysin-based " esistant gram-negative pathogens" to combat multidrug-resistant Gram-negative. mBio 5:e01379-14.

Briers Y, Walmagh M, Grymonprez B, et al. (2014b). Art-175 is a highly efficient antibacterial against multidrug-resistant strains and persisters of Pseudomonas aeruginosa. Antimicrob Agents Chemother 58:3774-84.

Brockmeier S, Halbur P, Thacker E. (2002). Porcine respiratory disease complex. In: Polymicrobial diseases. Washington (DC): ASM Press.

Caldentey J, Bamford DH. (1992). The lytic enzyme of the Pseudomonas phage phi 6. Purification and biochemical characterization. Biochim Biophys Acta 1159:44-50.

Callaway TR, Edrington TS, Brabban A, et al. (2010). Evaluation of phage treatment as a strategy to reduce Salmonella populations in growing swine. Foodborne Pathog Dis 8:261-66.

Celia LK, Nelson D, Kerr DE. (2008). Characterization of a bacteriophage lysin (Ply700) from Streptococcus uberis. Vet Microbiol 130:107-17.

Cha SB, Yoo AN, Lee WJ, et al. (2012). Effect of bacteriophage in enterotoxigenic Escherichia coli (ETEC) infected pigs. J Vet Med Sci 74:1037-39.

Chakraborty S, Kumar A, Tiwari R, et al. (2014). Advances in diagnosis of respiratory diseases of small ruminants. Vet Med Int 2014:598304.

Chhibber S, Kaur S, Kumari S. (2008). Therapeutic potential of bacteriophage in treating Klebsiella pneumoniae B5055mediated lobar pneumonia in mice. J Med Microbiol 57:1508-13.

Clark J, March J. (2006). Bacteriophages and biotechnology: vaccines, gene therapy and antibacterials. Trends Biotechnol 24:212-18.

Clark JR, March JB. (2004a). Bacterial viruses as human vaccines? Expert Rev Vaccines 3:463-76.

Clark JR, March JB. (2004b). Bacteriophage-mediated nucleic acid immunisation. FEMS Immunol Med Microbiol 40:21-26.

Clokie MRJ, Millard AD, Letarov AV, Heaphy S. (2011). Phages in nature. Bacteriophage 1:31-45.

Daniel A, Euler C, Collin M, et al. (2010). Synergism between a novel chimeric lysin and oxacillin protects against infection by methicillin-resistant Staphylococcus aureus. Antimicrob Agents Chemother 54:1603-12.

Díez-Martínez R, de Paz H, Bustamante N, et al. (2013). Improving the lethal effect of Cpl-7, a pneumococcal phage lysozyme with broad bactericidal activity, by inverting the net charge of its cell wall-binding module. Antimicrob Agents Chemother 57:5355-65.

Díez-Martínez R, De Paz HD, García-Fernández E, et al. (2015). A novel chimeric phage lysin with high in vitro and in vivo bactericidal activity against Streptococcus pneumoniae. J Antimicrob Chemother 70:1763-73.

Directive C. (2001). 2001/83/EC of 6 November 2001 community code relating to medicinal products for human use. Off J Eur Union L311:67-128.
Directive C. (2003). 2003/63/EC of 25 June 2003 amending directive 2001/83/EC on the community code relating to medicinal products for human use. Off J Eur Union L159:46-94.

Djurkovic S, Loeffler JM, Fischetti VA. (2005). Synergistic killing of Streptococcus pneumoniae with the bacteriophage lytic enzyme Cpl-1 and penicillin or gentamicin depends on the level of penicillin resistance. Antimicrob Agents Chemother 49:1225-28.

Doehn JM, Fischer K, Reppe K, et al. (2013). Delivery of the endolysin $\mathrm{Cpl}-1$ by inhalation rescues mice with fatal pneumococcal pneumonia. J Antimicrob Chemother 68:2111-17.

Dong Q, Wang J, Yang $\mathrm{H}$, et al. (2015). Construction of a chimeric lysin Ply187N-V12C with extended lytic activity against staphylococci and streptococci. Microb Biotechnol 8:210-20.

Donovan DM, Lardeo M, Foster-Frey J. (2006). Lysis of staphylococcal mastitis pathogens by bacteriophage phi11 endolysin. FEMS Microbiol Lett 265:133-39.

Drulis-Kawa Z, Majkowska-Skrobek G, Maciejewska B, et al. (2012). Learning from bacteriophages - advantages and limitations of phage and phage-encoded protein applications. Curr Protein Pept Sci 13:699-722.

Entenza JM, Loeffler JM, Grandgirard D, et al. (2005). Therapeutic effects of bacteriophage Cpl-1 lysin against Streptococcus pneumoniae endocarditis in rats. Antimicrob Agents Chemother 49:4789-92.

FAO Fisheries and Aquaculture Department [Internet]. c2014-2016. Cultured aquatic species information programme. Gadus morhua. Cultured aquatic species information program [updated Jan 2004, cited 2016]. Available from: http://www.fao.org/fishery/culturedspecies/Gadus morhua/en.

Fehér T, Karcagi I, Blattner FR, Pósfai G. (2012). Bacteriophage recombineering in the lytic state using the lambda red recombinases. Microb Biotechnol 5:466-76.

Fernandes S, Proença D, Cantante C, et al. (2012). Novel chimerical endolysins with broad antimicrobial activity against methicillin-resistant Staphylococcus aureus. Microbial Drug Res 18:333-43.

Fiorentin L, Vieira ND, Barioni W. Jr. (2005). Oral treatment with bacteriophages reduces the concentration of Salmonella enteritidis PT4 in caecal contents of broilers. Avian Pathol 34:258-63.

Fischetti VA. (2005). Bacteriophage lytic enzymes: novel antiinfectives. Trends Microbiol 13:491-96.

Folkerts G, Janssen M, Nijkamp FP. (1990). Parainfluenza-3 induced hyperreactivity of the guinea pig trachea coincides with an increased number of broncho-alveolar cells. Br J Clin Pharmacol 30:159S-61S.

Gaubin M, Fanutti C, Mishal Z, et al. (2003). Processing of filamentous bacteriophage virions in antigen-presenting cells targets both HLA class I and class II peptide loading compartments. DNA Cell Biol 22:11-18

Gill JJ, Hyman P. (2010). Phage choice, isolation, and preparation for phage therapy. Curr Pharm Biotechnol 11:2-14.

Gill JJ, Pacan JC, Carson ME, et al. (2006a). Efficacy and pharmacokinetics of bacteriophage therapy in treatment of subclinical Staphylococcus aureus mastitis in lactating dairy cattle. Antimicrob Agents Chemother 50:2912-18. 
Gill JJ, Sabour PM, Leslie KE, Griffiths MW. (2006b). Bovine whey proteins inhibit the interaction of Staphylococcus aureus and bacteriophage K. J Appl Microbiol 101:377-86.

Gilmer DB, Schmitz JE, Euler CW, Fischetti VA. (2013). Novel bacteriophage lysin with broad lytic activity protects against mixed infection by Streptococcus pyogenes and methicillin-resistant Staphylococcus aureus. Antimicrob Agents Chemother 57:2743-50.

Goodridge LD, Bisha B. (2011). Phage-based biocontrol strategies to reduce foodborne pathogens in foods. Bacteriophage 1:130-37.

Gu J, Xu W, Lei L, et al. (2011). LysGH15, a novel bacteriophage lysin, protects a murine bacteremia model efficiently against lethal methicillin-resistant Staphylococcus aureus infection. J Clin Microbiol 49:111-17.

Guy J. (1998). Virus infections of the gastrointestinal tract of poultry. Poult Sci 77:1166-75.

Hagens S, Habel A, von Ahsen U, et al. (2004). Therapy of experimental Pseudomonas infections with a nonreplicating genetically modified phage. Antimicrob Agents Chemother 48:3817-22.

Hao H, Cheng G, lqbal Z, et al. (2014). Benefits and risks of antimicrobial use in food-producing animals. Front Microbiol 5:288.

Haq IU, Chaudhry WN, Akhtar MN, et al. (2012). Bacteriophages and their implications on future biotechnology: a review. Virol J 9:9.

Hashemi H, Pouyanfard S, Bandehpour M, et al. (2012). Immunization with M2e-displaying T7 bacteriophage nanoparticles protects against influenza A virus challenge. PLoS One 7:e45765.

Hashiguchi S, Yamaguchi Y, Takeuchi O, et al. (2010). Immunological basis of M13 phage vaccine: regulation under MyD88 and TLR9 signaling. Biochem Biophys Res Commun 402:19-22.

Hayes S, Gamage LNA, Hayes C. (2010). Dual expression system for assembling phage lambda display particle (LDP) vaccine to porcine Circovirus 2 (PCV2). Vaccine 28:6789-99.

Heikkilä AM, Nousiainen Jl, Pyörälä S. (2012). Costs of clinical mastitis with special reference to premature culling. J Dairy Sci 95:139-50.

Hodgins D, Conlon J, Shewen P. 2002. Chapter 12 Respiratory viruses and bacteria in cattle. In: Polymicrobial diseases. Washington (DC): ASM Press.

Hollis A, Ahmed Z. (2013). Preserving antibiotics, rationally. N Engl J Med 369:2474-76.

Horgan M, O'Flynn G, Garry J, et al. (2009). Phage lysin LysK can be truncated to its CHAP domain and retain lytic activity against live antibiotic-resistant staphylococci. Appl Environ Microbiol 75:872-74.

Huff W, Huff G, Rath N, et al. (2003). Evaluation of aerosol spray and intramuscular injection of bacteriophage to treat an Escherichia coli respiratory infection. Poult Sci 82:1108-12.

Huff WE, Huff GR, Rath NC, et al. (2004). Therapeutic efficacy of bacteriophage and Baytril (enrofloxacin) individually and in combination to treat colibacillosis in broilers. Poult Sci 83:1944-47.

Huff WE, Huff GR, Rath NC, et al. (2002). Prevention of Escherichia coli respiratory infection in broiler chickens with bacteriophage (SPR02). Poult Sci 81:437-41.
Hung $\mathrm{C}-\mathrm{H}$, Kuo $\mathrm{C}-\mathrm{F}$, Wang $\mathrm{C}-\mathrm{H}$, et al. (2011). Experimental phage therapy in treating Klebsiella pneumoniae-mediated liver abscesses and bacteremia in mice. Antimicrob Agents Chemother 55:1358-65.

Hyman P, Abedon ST. 2010. Chapter 7 - Bacteriophage host range and bacterial resistance. In: Advances in applied microbiology. Cambridge (MA): Academic Press. 217-48.

Jado I, López R, García E, Network obotSPIS, et al. (2003). Phage lytic enzymes as therapy for antibiotic-resistant Streptococcus pneumoniae infection in a murine sepsis model. J Antimicrob Chemother 52:967-73.

Jamalludeen N, Johnson RP, Shewen PE, Gyles CL. (2009). Evaluation of bacteriophages for prevention and treatment of diarrhea due to experimental enterotoxigenic Escherichia coli 0149 infection of pigs. Vet Microbiol 136:135-41.

Jones KE, Patel NG, Levy MA, et al. (2008). Global trends in emerging infectious diseases. Nature 451:990-93.

Jun SY, Jung GM, Yoon SJ, et al. (2014). Preclinical safety evaluation of intravenously administered SAL200 containing the recombinant phage endolysin SAL-1 as a pharmaceutical ingredient. Antimicrob Agents Chemother 58:2084-88.

Jun SY, Jung GM, Yoon SJ, et al. (2012). Antibacterial properties of a pre-formulated recombinant phage endolysin, SAL-1. Int J Antimicrob Agents 41:156-61.

Kapil S, Basaraba R. (1997). Infectious bovine rhinotracheitis, parainfluenza-3, and respiratory coronavirus. Vet Clin North Am Food Anim Pract 13:455-69.

Keen EC. (2012). Phage therapy: concept to cure. Front Microbiol 3:238.

Kim K-R, Owens G, Kwon S-I, et al. (2011). Occurrence and environmental fate of veterinary antibiotics in the terrestrial environment. Water Air Soil Pollut 214:163-74.

Kiro R, Shitrit D, Qimron U. (2014). Efficient engineering of a bacteriophage genome using the type I-E CRISPR-Cas system. RNA Biol 11:42-44.

Krieg AM, Yi A-K, Matson S, et al. (1995). CpG motifs in bacterial DNA trigger direct B-cell activation. Nature 374:546-49.

Kutter E, De Vos D, Gvasalia G, et al. (2010). Phage therapy in clinical practice: treatment of human infections. Curr Pharm Biotechnol 11:69-86.

Kutter E, Sulakvelidze A. 2005. Bacteriophages: biology and application. Boca Raton (FL): CRC Press.

Labrie SJ, Samson JE, Moineau S. (2010). Bacteriophage resistance mechanisms. Nat Rev Microbiol 8:317-27.

Lai M-J, Lin N-T, Hu A, et al. (2011). Antibacterial activity of Acinetobacter baumannii phage $\phi A B 2$ endolysin (LysAB2) against both Gram-positive and Gram-negative bacteria. Appl Microbiol Biotechnol 90:529-39.

Lamy E, Harten S, Sales-Baptista E, Guerra M, Almeida A. 2012. Factors influencing livestock productivity. In: Environmental stress and amelioration in livestock production. Berlin: Springer Berlin Heidelberg. 19-51.

Lavigne R, Briers Y, Hertveldt K, et al. (2004). Identification and characterization of a highly thermostable bacteriophage lysozyme. Cell Mol Life Sci 61:2753-59.

Lawrence DG. (2010). Designing phage therapeutics. Curr Pharm Biotechnol 11:15-27.

Lee N, Harris D. 2001. The effect of bacteriophage treatment to reduce the rapid dissemination of Salmonella typhimurium in pigs. Swine Res Report. Paper 50. 
Letellier L, Plançon L, Bonhivers M, Boulanger P. (1999). Phage DNA transport across membranes. Res Microbiol 150:499-505.

Li Q, Shivachandra SB, Leppla SH, Rao VB. (2006). Bacteriophage T4 capsid: a unique platform for efficient surface assembly of macromolecular complexes. J Mol Biol 363:577-88.

Lim J-A, Shin H, Heu S, Ryu S. (2014). Exogenous lytic activity of SPN9CC endolysin against Gram-negative bacteria. J Microbiol Biotechnol 24:803-11.

Lim T-H, Kim M-S, Lee D-H, et al. (2012). Use of bacteriophage for biological control of Salmonella Enteritidis infection in chicken. Res Vet Sci 93:1173-78.

Lima D, Furian T, Pillati R, et al. (2016). Establishment of a pathogenicity index in Salmonella Enteritidis and Salmonella Typhimurium strains inoculated in one-day-old broiler chicks. Arq Bras Med Vet Zootec 68:257-64.

Loc-Carrillo C, Abedon ST. (2011). Pros and cons of phage therapy. Bacteriophage 1:111-14.

Loeffler JM, Djurkovic S, Fischetti VA. (2003). Phage lytic enzyme Cpl-1 as a novel antimicrobial for Pneumococcal bacteremia. Infect Immun 71:6199-204.

Loeffler JM, Fischetti VA. (2003). Synergistic lethal effect of a combination of phage lytic enzymes with different activities on penicillin-sensitive and -resistant Streptococcus pneumoniae strains. Antimicrob Agents Chemother 47:375-77.

Loeffler JM, Nelson D, Fischetti VA. (2001). Rapid killing of Streptococcus pneumoniae with a bacteriophage cell wall hydrolase. Science 294:2170-72.

Lood R, Raz A, Molina H, et al. (2014). A highly active and negatively charged Streptococcus pyogenes lysin with a rare d-alanyl-I-alanine endopeptidase activity protects mice against Streptococcal bacteremia. Antimicrob Agents Chemother 58:3073-84.

Lu T, Koeris N, Chevalier B, et al. 2013. Recombinant phage and methods. Sample6 Technologies, Inc. United States patent US 13/627,060.

Lu TK, Collins JJ. (2007). Dispersing biofilms with engineered enzymatic bacteriophage. Proc Natl Acad Sci USA 104:11197-202.

Lu TK, Collins JJ. (2009). Engineered bacteriophage targeting gene networks as adjuvants for antibiotic therapy. Proc Natl Acad Sci USA 106:4629-34.

Ly-Chatain MH. (2014). The factors affecting effectiveness of treatment in phages therapy. Front Microbiol 5:51.

Magyar T, Lax AJ. 2002. Atrophic rhinitis. Chapter 10. In: Brodgen KA, Guthmiller JM, eds. Polymicrobial diseases. Washington (DC): ASM Press.

Manoharadas S, Witte A, Bläsi U. (2009). Antimicrobial activity of a chimeric enzybiotic towards Staphylococcus aureus. J Biotechnol 139:118-23.

Mao J, Schmelcher M, Harty WJ, et al. (2013). Chimeric Ply187 endolysin kills Staphylococcus aureus more effectively than the parental enzyme. FEMS Microbiol Lett 342:30-36.

Marinelli L, Hatfull G, Piuri M. (2012). Recombineering: a powerful tool for modification of bacteriophage genomes. Bacteriophage 2:5-14.

Marinelli LJ, Piuri M, Swigoňová Z, et al. (2008). BRED: a simple and powerful tool for constructing mutant and recombinant bacteriophage genomes. PLoS One 3:e3957.
Martel B, Moineau S. (2014). CRISPR-Cas: an efficient tool for genome engineering of virulent bacteriophages. Nucleic Acids Res 42:9504-13.

Masdooq A, Salihu A, Muazu A, et al. (2008). Pathogenic bacteria associated with respiratory disease in poultry with reference to pasteurella multocida. Int J Poult Sci 7:674-75.

Mason KA, Ariga H, Neal R, et al. (2005). Targeting toll-like receptor 9 with $\mathrm{cpg}$ oligodeoxynucleotides enhances tumor response to fractionated radiotherapy. Clin Cancer Res 11:361-69.

Matsuda T, Freeman TA, Hilbert DW, et al. (2005). Lysis-deficient bacteriophage therapy decreases endotoxin and inflammatory mediator release and improves survival in a murine peritonitis model. Surgery 137:639-46.

McCullers JA, Karlström $\AA$, Iverson AR, et al. (2007). Novel strategy to prevent otitis media caused by colonizing Streptococcus pneumoniae. PLoS Pathog 3:e28.

Mellon M, Benbrock C, Benbrock K. 2001. Hogging it: estimates of antimicrobial abuse in livestock. Cambridge (MA): Union of Concerned Scientists.

Merck [Internet]. 2015. The Merck veterinary manual; [cited 2015]. Available from: http://www.merckvetmanual.com/.

Moak M, Molineux IJ. (2004). Peptidoglycan hydrolytic activities associated with bacteriophage virions. Mol Microbiol 51:1169-83.

Morita M, Tanji Y, Mizoguchi K, et al. (2001a). Antibacterial activity of Bacillus amyloliquefaciens phage endolysin without holin conjugation. J Biosci Bioeng 91:469-73.

Morita M, Tanji Y, Orito Y, et al. (2001b). Functional analysis of antibacterial activity of Bacillus amyloliquefaciens phage endolysin against Gram-negative bacteria. FEBS Lett 500:56-59.

Müller H, Islam MR, Raue R. (2003). Research on infectious bursal disease-the past, the present and the future. Vet Microbiol 97:153-65.

Mushtaq N, Redpath MB, Luzio JP, Taylor PW. (2005). Treatment of experimental Escherichia coli infection with recombinant bacteriophage-derived capsule depolymerase. J Antimicrob Chemother 56:160-65.

Nedbalcova K, Satran P, Jaglic Z, et al. (2006). Haemophilus parasuis and Glässer's disease in pigs: a review. Vet Med Czech 51:168-79.

Nelson D, Loomis L, Fischetti VA. (2001). Prevention and elimination of upper respiratory colonization of mice by group A streptococci by using a bacteriophage lytic enzyme. Proc Natl Acad Sci USA 98:4107-12.

Nobrega FL, Costa AR, Kluskens LD, Azeredo J. (2015). Revisiting phage therapy: new applications for old resources. Trends Microbiol 23:185-91.

O'Flaherty S, Coffey A, Meaney WJ, et al. (2005). Inhibition of bacteriophage $\mathrm{K}$ proliferation on Staphylococcus aureus in raw bovine milk. Lett Appl Microbiol 41:274-79.

O'Flaherty S, Ross RP, Coffey A. (2009). Bacteriophage and their lysins for elimination of infectious bacteria. FEMS Microbiol Rev 33:801-19.

Obeso JM, Martínez B, Rodríguez A, García P. (2008). Lytic activity of the recombinant staphylococcal bacteriophage $\Phi \mathrm{H} 5$ endolysin active against Staphylococcus aureus in milk. Int J Food Microbiol 128:212-18.

Oechslin F, Daraspe J, Giddey M, et al. (2013). In vitro characterization of PlySK1249, a novel phage lysin, and 
assessment of its antibacterial activity in a mouse model of Streptococcus agalactiae bacteremia. Antimicrob Agents Chemother 57:6276-83.

Oliveira A, Sereno R, Azeredo J. (2010). In vivo efficiency evaluation of a phage cocktail in controlling severe colibacillosis in confined conditions and experimental poultry houses. Vet Microbiol 146:303-8.

Oliveira H, Melo LDR, Santos SB, et al. (2013). Molecular aspects and comparative genomics of bacteriophage endolysins. J Virol 87:4558-70.

Olofsson L, Söderberg P, Ankarloo J, Nicholls I. (2008). Phage display screening in low dielectric media. J Mol Recognit 21:330-37.

Orito Y, Morita M, Hori K, et al. (2004). Bacillus amyloliquefaciens phage endolysin can enhance permeability of Pseudomonas aeruginosa outer membrane and induce cell lysis. Appl Microbiol Biotechnol 65:105-9.

Örmälä A-M, Jalasvuori M. (2013). Phage therapy: should bacterial resistance to phages be a concern, even in the long run? Bacteriophage 3:e24219.

Ou C, Tian D, Ling Y, et al. (2013). Evaluation of an ompAbased phage-mediated DNA vaccine against Chlamydia abortus in piglets. Int Immunopharmacol 16:505-10.

Page S, Gautier P. (2012). Use of antimicrobial agents in livestock. Rev Sci Tech 31:145-88.

Pastagia M, Euler C, Chahales P, et al. (2011). A novel chimeric lysin shows superiority to mupirocin for skin decolonization of methicillin-resistant and -sensitive Staphylococcus aureus strains. Antimicrob Agents Chemother 55:738-44.

Paul VD, Rajagopalan SS, Sundarrajan S, et al. (2011). A novel bacteriophage tail-associated muralytic enzyme (TAME) from Phage $\mathrm{K}$ and its development into a potent antistaphylococcal protein. BMC Microbiol 11:1-11.

Persson G, Bojesen A. (2015). Bacterial determinants of importance in the virulence of Gallibacterium anatis in poultry. Vet Res 46:57.

Phillips I, Casewell M, Cox T, et al. (2004). Does the use of antibiotics in food animals pose a risk to human health? A critical review of published data. J Antimicrob Chemother 53:28-52.

Pires DP, Cleto S, Sillankorva S, et al. (2016). Genetically engineered phages: a review of advances over the last decade. Microbiol Mol Biol Rev 80:523-43.

Prisco A, De Berardinis P. (2012). Filamentous bacteriophage $\mathrm{Fd}$ as an antigen delivery system in vaccination. Int $\mathrm{J} \mathrm{Mol}$ Sci 13:5179-94.

Ramesh V, Fralick JA, Rolfe RD. (1999). Prevention of Clostridium difficile-induced ileocecitis with bacteriophage. Anaerobe 5:69-78.

Rashel M, Uchiyama J, Takemura I, et al. (2008). Tail-associated structural protein gp61 of Staphylococcus aureus phage $\varphi M R 11$ has bifunctional lytic activity. FEMS Microbiol Lett 284:9-16.

Rashel M, Uchiyama J, Ujihara T, et al. (2007). Efficient elimination of multidrug-resistant Staphylococcus aureus by cloned lysin derived from bacteriophage $\phi M R 11$. J Infect Dis 196:1237-47.

Ren ZJ, Tian CJ, Zhu QS, et al. (2008). Orally delivered footand-mouth disease virus capsid protomer vaccine displayed on T4 bacteriophage surface: $100 \%$ protection from potency challenge in mice. Vaccine 26:1471-81.
Rodríguez-Cerrato V, García P, del Prado G, et al. (2007). In vitro interactions of LytA, the major pneumococcal autolysin, with two bacteriophage lytic enzymes (Cpl-1 and Pal), cefotaxime and moxifloxacin against antibiotic-susceptible and -resistant Streptococcus pneumoniae strains. J Antimicrob Chemother 60:1159-62.

Rodríguez-Rubio L, Martínez B, Donovan DM, et al. (2013). Potential of the virion-associated peptidoglycan hydrolase $\mathrm{HydH} 5$ and its derivative fusion proteins in milk biopreservation. PLoS One 8:e54828.

Rodríguez-Rubio L, Martínez B, Rodríguez A, et al. (2012). Enhanced staphylolytic activity of the Staphylococcus aureus bacteriophage vB_SauS-philPLA88 HydH5 virion-associated peptidoglycan hydrolase: fusions, deletions, and synergy with LysH5. Appl Environ Microbiol 78:2241-48.

Rodríguez L, Martínez B, Zhou Y, et al. (2011). Lytic activity of the virion-associated peptidoglycan hydrolase $\mathrm{HydH} 5$ of Staphylococcus aureus bacteriophage vB_SauS-philPLA88. BMC Microbiol 11:1-11.

Royster E, Wagner S. 2015. Treatment of mastitis in cattle. Vet Clin North Am Food Anim Pract 31:17-46.

Saez AC, Zhang J, Rostagno MH, Ebner PD. (2011). Direct feeding of microencapsulated bacteriophages to reduce Salmonella colonization in pigs. Foodborne Pathog Dis 8:1269-74.

Saif LJ. (2010). Bovine respiratory coronavirus. Vet Clin North Am Food Anim Pract 26:349-64.

Schmelcher M, Donovan DM, Loessner MJ. (2012a). Bacteriophage endolysins as novel antimicrobials. Future Microbiol 7:1147-71.

Schmelcher M, Powell AM, Becker SC, et al. (2012b). Chimeric phage lysins act synergistically with lysostaphin to kill mastitis-causing Staphylococcus aureus in murine mammary glands. Appl Environ Microbiol 78:2297-305.

Schmelcher M, Powell AM, Camp MJ, et al. (2015a). Synergistic streptococcal phage $\lambda \mathrm{SA} 2$ and B30 endolysins kill streptococci in cow milk and in a mouse model of mastitis. Appl Microbiol Biotechnol 99:8475-86.

Schmelcher M, Shen Y, Nelson DC, et al. (2015b). Evolutionarily distinct bacteriophage endolysins featuring conserved peptidoglycan cleavage sites protect mice from MRSA infection. J Antimicrob Chemother 70:1453-65.

Schmelcher M, Tchang VS, Loessner MJ. (2011). Domain shuffling and module engineering of Listeria phage endolysins for enhanced lytic activity and binding affinity. Microb Biotechnol 4:651-62.

Scholl D, Adhya S, Merril C. (2005). Escherichia coli K1's capsule is a barrier to bacteriophage T7. Appl Environ Microbiol 71:4872-4.

Schuch R, Nelson D, Fischetti VA. (2002). A bacteriolytic agent that detects and kills Bacillus anthracis. Nature 418:884-89.

Shi Y, Li N, Yan Y, et al. (2012). Combined antibacterial activity of phage lytic proteins holin and lysin from Streptococcus suis bacteriophage SMP. Curr Microbiol 65:28-34.

Sidhu SS. (2000). Phage display in pharmaceutical biotechnology. Curr Opin Biotechnol 11:610-16.

Siegrist C-A. 2012. Vaccine immunology. In: Vaccines. Saunders. 14-32.

Sklar IB, Joerger RD. (2001). Attempts to utilize bacteriophage to combat Salmonella enterica serovar enteritidis infection in chickens. J Food Safety 21:15-29. 
Smith G. (1985). Filamentous fusion phage: novel expression vectors that display cloned antigens on the virion surface. Science 228:1315-17.

Smith H, Huggins M. (1983). Effectiveness of phages in treating experimental Escherichia coli diarrhoea in calves, piglets and lambs. J Gen Microbiol 129:2659-75.

Soothill JS. (1992). Treatment of experimental infections of mice with bacteriophages. J Med Microbiol 37:258-61.

Sulakvelidze A, Alavidze Z, Morris JG. (2001). Bacteriophage therapy. Antimicrob Agents Chemother 45:649-59.

Sundell GN, Ivarsson Y. (2014). Interaction analysis through proteomic phage display. BioMed Res Int 2014:176172. doi:10.1155/2014/176172.

Takáč M, Bläsi U. (2005). Phage P68 virion-associated protein 17 displays activity against clinical isolates of Staphylococcus aureus. Antimicrob Agents Chemother 49:2934-40.

Toro H, Price S, McKee A, et al. (2005). Use of bacteriophages in combination with competitive exclusion to reduce Salmonella from infected chickens. Avian Dis 49:118-24.

Torres-Medina A, Schlafer D, Mebus C. (1985). Rotaviral and coronaviral diarrhea. Vet Clin North Am Food Anim Pract 1:471-93.

Uchiyama J, Rashel M, Takemura I, et al. (2008). In silico and in vivo evaluation of bacteriophage phiEF24C, a candidate for treatment of Enterococcus faecalis infections. Appl Environ Microbiol 74:4149-63.

Van Boeckel TP, Brower C, Gilbert M, et al. (2015). Global trends in antimicrobial use in food animals. Proc Natl Acad Sci USA 112:5649-54.

Verbeken G, De Vos D, Vaneechoutte M, et al. (2007). European regulatory conundrum of phage therapy. Future Microbiol, 2:485-91.

VetBac [Internet] 2015. Veterinary bacteriology: information about important bacteria; [cited 2015]. Available from: http://www.vetbact.org/vetbact/?startpage $=1$.

Vinodkumar C, Kalsurmath S, Neelagund Y. (2008). Utility of lytic bacteriophages in the treatment of multidrug-resistant Pseudomonas aeruginosa septicemia in mice. Ind J Pathol Microbiol 51:360-66.

Vitiello CL, Merril CR, Adhya S. (2005). An amino acid substitution in a capsid protein enhances phage survival in mouse circulatory system more than a 1000-fold. Virus Res 114:101-3.

Vogel G, Nicolet J, Martig J, et al. (2001). Pneumonia in calves: characterization of the bacterial spectrum and the resistance patterns to antimicrobial drugs. Schweiz Arch Tierheilkd 143:341-50.

Wall SK, Zhang J, Rostagno MH, Ebner PD. (2010). Phage therapy to reduce preprocessing Salmonella infections in market-weight swine. Appl Environ Microbiol 76:48-53.

Walmagh M, Boczkowska B, Grymonprez B, et al. (2012a). Characterization of five novel endolysins from Gram- negative infecting bacteriophages. Appl Microbiol Biotechnol 97:4369-75.

Walmagh M, Briers Y, Santos SBd, et al. (2012b). Characterization of modular bacteriophage endolysins from Myoviridae phages OBP, 201 2 2-1 and PVP-SE1. PLoS One 7:e36991.

Wang I-N, Smith DL, Young R. (2000). Holins: the protein clocks of bacteriophage infections. Annu Rev Microbiol 54:799-825.

Wang J, Hu B, Xu M, et al. (2006). Use of bacteriophage in the treatmnt of experimental animal bacteremia from imipenem-resistant Pseudomonas aeruginosa. Int J Mol Med 17:309-17.

Wang Y, Sun JH, Lu CP. (2009). Purified recombinant phage lysin LySMP: an extensive spectrum of lytic activity for swine streptococci. Curr Microbiol 58:609-15.

Waseh S, Hanifi-Moghaddam P, Coleman R, et al. (2010). Orally administered $\mathrm{P} 22$ phage tailspike protein reduces Salmonella colonization in chickens: prospects of a novel therapy against bacterial infections. PLoS One 5:e13904.

WHO [Internet]. 2015. Foodborne diseases; [cited 2015] Available from: http://apps.who.int/foodsafety/areas_work/ foodborne-diseases/en/index.html.

Witzenrath M, Schmeck B, Doehn JM, et al. (2009). Systemic use of the endolysin $\mathrm{Cpl}-1$ rescues mice with fatal pneumococcal pneumonia. Crit Care Med 37:642-49.

Woolhouse MEJ, Haydon DT, Antia R. (2005). Emerging pathogens: the epidemiology and evolution of species jumps. Trends Ecol Evol (Amst.) 20:238-44.

Wu J, Tu C, Yu X, et al. (2007). Bacteriophage T4 nanoparticle capsid surface SOC and HOC bipartite display with enhanced classical swine fever virus immunogenicity: a powerful immunological approach. J Virol Methods 139:50-60.

Yang H, Yu J, Wei H. (2014a). Engineered bacteriophage lysins as novel anti-infectives. Front Microbiol 5:542.

Yang H, Zhang Y, Yu J, et al. (2014b). Novel chimeric lysin with high-level antimicrobial activity against methicillinresistant Staphylococcus aureus in vitro and in vivo. Antimicrob Agents Chemother 58:536-42.

Yoichi M, Abe M, Miyanaga K, et al (2005). Alteration of tail fiber protein gp38 enables T2 phage to infect Escherichia coli 0157:H7 J Biotechnol 115:101-7.

Young R. (2013). Phage lysis: do we have the hole story yet? Curr Opin Microbiol 16:790-97.

Young R. (2014). Phage lysis: three steps, three choices, one outcome. J Microbiol 52:243-58.

Zanghi CN, Sapinoro R, Bradel-Tretheway B, Dewhurst S. (2007). A tractable method for simultaneous modifications to the head and tail of bacteriophage lambda and its application to enhancing phage-mediated gene delivery. Nucleic Acids Res 35:e59. 